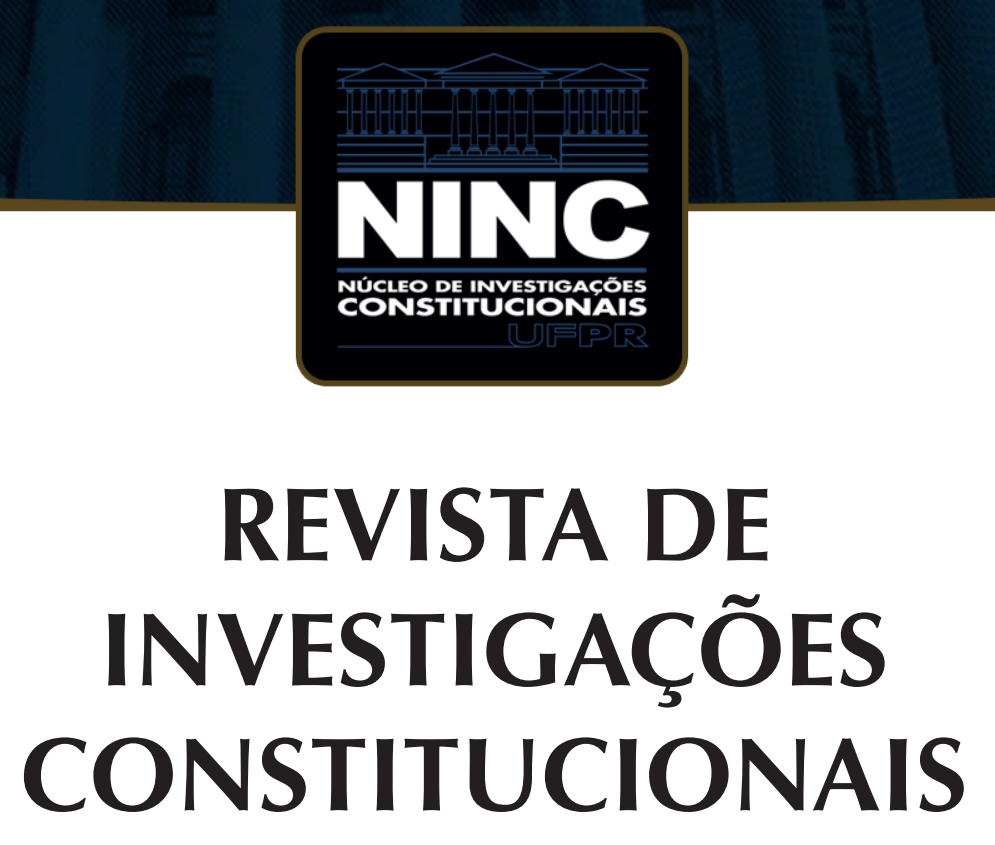

JOURNAL OF CONSTITUTIONAL RESEARCH

vol. 7 | n. 2 | maio/agosto 2020 | ISSN 2359-5639 | Periodicidade quadrimestral Curitiba | Núcleo de Investigações Constitucionais da UFPR | www.ninc.com.br 


\title{
Quando o estado de coisas é inconstitucional: sobre o lugar do Poder Judiciário no problema carcerário
}

\section{When the state of affairs is unconstitutional: about the judiciary position in the incarceration problem}

\author{
MAIRA ROCHA MACHADO ${ }^{1, *}$ \\ ' Fundação Getúlio Vargas - FGV/SP (São Paulo, São Paulo, Brasil) \\ maira.machado@fgv.br \\ https://orcid.org/0000-0003-1303-5790 \\ Recebido/Received: 25.07.2018 / July $25^{\text {th }}, 2018$ \\ Aprovado/Approved: 26.10 .2020 / October $26^{\text {th }}, 2020$
}

Resumo

O objetivo do presente texto é realizar uma análise documental de relatórios, decisões judiciais e pesquisas que contribuam a refletir sobre o papel desempenhado pelo poder judiciário no enfrentamento do problema carcerário. Para tanto, o texto parte do contexto latino-americano, revelando as semelhanças da situação das prisões brasileiras com inúmeras outras do continente, o que nos convida a refletir sobre as possibilidades de intercâmbio e aprendizado com as experiências de outros países. Diante disso, o artigo sistematiza e compara as decisões das cortes constitucionais colombiana e brasileira que declararam o estado de coisas inconstitucional dos sistemas prisionais desses países. E, em seguida, discute os limites da decisão colombiana e o que podemos aprender
Abstract

This paper presents the results of a documental analysis in reports, judicial decisions and academic research concerning the role of the judiciary power in the incarceration problem. It departs from the Latin American context to reveal the similarities between Brazilian prison conditions and many others in the continent. This scenario invites us to focus on the possibilities of mutual learning among our countries. In view of that, the paper systematizes and compares Supreme Court decisions from Colombia and Brazil that declares the "unconstitutional state of affairs" of their prison systems. And then discusses the limits of the Colombian decision and what we can learn from this experience to rethink about ways to deal with the prison problem in Brazil. To expand this analysis to the lower courts, the last part of

Como citar esse artigo/How to cite this article: MACHADO, Maira Rocha. Quando o estado de coisas é inconstitucional: sobre o lugar do Poder Judiciário no problema carcerário. Revista de Investigações Constitucionais, Curitiba, vol. 7, n. 2, p. 631-664, maio/ago. 2020. DOI: 10.5380/rinc.v7i2.60692.

* Professora da Graduação e do Mestrado Acadêmico da Fundação Getúlio Vargas - FGV Direito SP (São Paulo-SP, Brasil). Doutora em Direito pela Universidade de São Paulo. E-mail: maira.machado@fgv.br. 
com ela para refletir sobre o problema carcerário no Brasil. Debruça-se também sobre o potencial dos pedidos formulados pelos autores da ADPF 347 para promover o desencarceramento e enfrentar, no longo prazo, o problema carcerário. Para não restringir essa análise dos tribunais superiores, a parte final do artigo focaliza as decisões do Tribunal de Justiça de São Paulo em ações civis públicas sobre o problema carcerário. E, por fim, aponta questões em aberto para novas pesquisas.

Palavras-chave: encarceramento; separação de poderes; estado de coisas inconstitucional; ações civis públicas; América Latina. the article exams São Paulo Appeal Court (TJSP) decisions in public civil actions concerning the incarceration problem.

Keywords: incarceration; separation of powers; unconstitutional state of affairs; public civil action; Latin America.

"O problema carcerário é puramente de investimento do estado. Deveria o Judiciário simplesmente libertar os presos que representam risco à população para solucionar um problema do Executivo? ?"m** $^{\prime}$

\section{SUMÁRIO}

1. Introdução; 2. O problema carcerário no contexto latino-americano; 3. As decisões na Colômbia e no Brasil; 4. As fissuras no modelo cristalizado de separação de poderes; 5. A repercussão no TJSP; 6. Considerações finais; 7 . Referências.

\section{INTRODUÇÃO}

O trecho em epígrafe, entre vários outros da mesma entrevista, coloca diretamente em questão o papel do poder judiciário diante do assim chamado "problema carcerário".1 Vocaliza um modo ainda bastante difundido de observar as pessoas privadas de liberdade, ao distinguir "os presos que representam risco" do conjunto da "população", e o modo como dividimos as tarefas em matéria de penas. Este texto se debruça sobre esse segundo ponto, ainda que, como se verá, esteja de várias formas relacionado a essa clivagem histórica entre um "nós" e um "eles".

\footnotetext{
"* Trechos de entrevista de Patrícia Álvares Cruz, Juíza de Direito, Corregedora do Departamento de Inquéritos Policiais, ao jornal Folha de São Paulo em 12.03.2018.

1 Praticamente todo o conteúdo da entrevista em epígrafe convida à reflexão sobre as percepções de magistradas e magistrados sobre as condutas criminalizáveis e sobre o funcionamento do sistema de justiça criminal. O presente texto se limita apenas a um deles. Mas diversos outros pontos podem e devem ser escrutinados e confrontados com o estoque de conhecimento disponível no campo do direito e das ciências sociais.
} 
Aqui, esse modo difundido de observar a divisão de tarefas em matéria de penas será denominado "modelo cristalizado de separação de poderes". De acordo com essa formulação, que tem sido útil para refletir sobre uma série de questões no campo criminal, o que ocorre nas prisões é problema do executivo, a qualidade e a quantidade da pena imposta são problema do legislativo, e ao judiciário cabe ater-se à aplicação da lei para não decidir em função das opiniões pessoais das magistradas e magistrados.

Como se vê na entrevista em epígrafe, mas também em discursos públicos e decisões judiciais sobre diferentes temas, esse modelo cristalizado ainda corresponde ao modo como diversas pessoas que atuam no sistema de justiça criminal compreendem suas atividades profissionais. Nesse modelo cristalizado, muitos atores intervêm mas nenhum deles se percebe como responsável pelos resultados produzidos coletivamente. A ideia de "separação de poderes" associa-se então a uma enorme engrenagem em que "cada um faz o seu" e se observa como indiferente em relação ao conjunto da obra.

Mas é possível observar também, sobretudo nos últimos anos, o surgimento de fissuras nesse modelo, isto é, o surgimento de outras formas de observar o problema carcerário e o modo como os três poderes, individual e conjuntamente, podem contribuir tanto para agravá-lo quanto para solucioná-lo (ou minimizá-lo).

A ADPF 347 sobre o "estado de coisas inconstitucional" do sistema prisional brasileiro constitui um exemplo eloquente dessa fissura. ${ }^{2}$ Não pelo resultado tímido do julgamento da medida cautelar, mas sim por três ordens de fatores, que serão discutidas aqui: pela força comunicativa da declaração do estado de coisas inconstitucional de nosso sistema prisional, pelo modo como essa afirmação está reverberando em outros tribunais e, sobretudo, pelo teor dos pedidos formulados pelo autor da ação, o Partido Socialismo e Liberdade - PSOL, que direcionam nossa atenção aos mecanismos jurídicos que estão a nossa disposição para enfrentar o problema carcerário.

Também em 2015, poucas semanas antes do julgamento da ADPF 347, o STF deu provimento ao RE 592.581/RS, por unanimidade, com repercussão geral, estabelecendo que o judiciário pode impor obrigações ao executivo, promovendo medidas e executando obras em estabelecimentos prisionais, com vistas a dar efetividade ao princípio da dignidade humana e assegurar às pessoas em privação de liberdade o respeito à sua dignidade física e moral. ${ }^{3}$ Essa decisão afasta explicitamente a utilização

2 BRASIL. Supremo Tribunal Federal. Acórdão. Arguição de Descumprimento de Preceito Fundamental (ADPF) n³47. Relator: Min. Marco Aurélio. Brasília, DF. Publicado em: 19 fev. 2016. Disponível em: <http://redir. stf.jus.br/paginadorpub/paginador.jsp?docTP=TP\&docID=10300665>. Acesso em: 26 mar. 2018. Em diante, ADPF 347.

3 BRASIL. Supremo Tribunal Federal. Recurso Extraordinário n. ${ }^{5}$ 592.581/RS. Recorrente: Ministério Público do Rio Grande do Sul. Recorrido: Estado do Rio Grande do Sul. Relator: Ministro Ricardo Lewandowski. Brasília, 01 de fevereiro de 2016. Disponível em < http://portal.stf.jus.br/processos/detalhe.asp?incidente=2637302>. Acesso em 28 de março de 2018. Em diante, RE 592.581. 
do argumento da "separação de poderes" que vinha sendo sistematicamente mobilizado pelos tribunais para atribuir a responsabilidade pelo problema carcerário ao poder executivo.

Diante desse quadro, o objetivo do presente texto é realizar uma análise documental de relatórios, decisões judiciais e pesquisas que nos ajude a observar o alcance e as implicações do modelo cristalizado de separação de poderes e das fissuras que estão surgindo. Buscar-se-á explorar um modo de abordar o problema carcerário que focaliza as interações entre legislativo, judiciário e executivo em matéria de gestão da pena. Atenta-se aqui aos três poderes, ciente que outras instâncias - a mídia, a própria dogmática, os movimentos sociais - também poderiam beneficiar e ser beneficiados por este de tipo de abordagem. Como em qualquer outra estratégia de pesquisa, não conseguimos observar tudo ao mesmo tempo e, por isso, esse texto elege o judiciário, em suas interações sobretudo com o executivo, como porta de entrada. Esse mesmo tipo de abordagem contaria outras histórias a partir do legislativo ou do executivo.

Na formulação proposta aqui, pensar nessas interações é pensar nas concepções que cada um tem do outro, concepções que pautam, e muitas vezes condicionam, a forma como cada um de nós atua. Ao focalizar as interações e as percepções mútuas, busca-se favorecer uma forma de construção coletiva em que todo mundo perde quando esvazia ou retrai seu campo de atuação, atribuindo aos demais a responsabilidade pelos efeitos que, juntos, causamos. Em outras palavras, ao atribuirmos a responsabilidade aos demais poderes lavamos nossas mãos, tornando-nos indiferentes ao resultado global, aos efeitos que são produzidos com a nossa participação (ainda que indiferente). Esse tipo de abordagem nos convida a observar justamente os mecanismos de atribuição de responsabilidade externa e também de isenção de responsabilidade interna diante do problema carcerário.

Para avançar sobre essas questões, esse artigo está dividido em seis partes. Após esta introdução, a seção 2 dedica-se a apresentar o problema carcerário no contexto latino-americano. Como se verá, a situação das prisões brasileiras guarda uma série de semelhanças com inúmeras outras do continente, o que nos convida a levar a sério as possibilidades de intercâmbio e aprendizado com as experiências de outros países. Justamente em virtude disso, a seção 3 sistematiza e compara as decisões das cortes constitucionais colombiana e brasileira que declararam o estado de coisas inconstitucional dos sistemas prisionais desses países. Em seguida, a seção 4 discute os limites da decisão colombiana e o que podemos aprender com ela para refletir sobre o problema carcerário no Brasil. Essa seção debruça-se também sobre o potencial dos pedidos formulados pelos autores da ADPF 347 para promover o desencarceramento e enfrentar, no longo prazo, o problema carcerário. Para não restringir essa análise aos tribunais superiores, a seção 5 busca avançar a reflexão sobre o lugar do poder judiciário em face do problema carcerário focalizando as decisões do Tribunal de Justiça de São Paulo em 
ações civis públicas. A seção final sintetiza o percurso do texto e aponta questões em aberto para novas pesquisas.

\section{O PROBLEMA CARCERÁRIO NO CONTEXTO LATINO-AMERICA- NO}

Na Colômbia e no Brasil, como em diversos outros países latino-americanos, a gravidade da situação penitenciária vem sendo sistematicamente denunciada4. "Bombas de tempo que podem explodir a qualquer momento" - assim Sergio García Ramírez, jurista mexicano e juiz da IACHR, descreve a situação das prisões do continente diante do "maltrato absoluto dos reclusos, da irracionalidade dos castigos que se infligem muros adentro, do despreparo e sevícia dos funcionários (...)".5

E não é de hoje. O historiador peruano Carlos Aguirre, em seu estudo sobre as prisões na América Latina, analisa a recepção do penitenciarismo na primeira metade do século XIX como um "novo padrão de encarceramento" que combinava um desenho arquitetônico com uma "rotina altamente regimentada de trabalho e instrução, um sistema de vigilância permanente sobre os detidos, um tratamento supostamente humanitário e o ensino da religião aos presos"6. No decorrer desse período, foram construídas penitenciárias no Rio de Janeiro, Santiago do Chile, Lima, Quito e Buenos Aires, fortemente inspiradas em modelos provenientes dos Estados Unidos da América. Isoladas nas grandes capitais do continente, a construção de penitenciárias "não foi seguida pela implementação de mudanças similares no resto do sistema carcerário de cada país"7. A pesquisa de Aguirre revela que a reforma penitenciarista fracassou no continente latino-americano tanto por "impedimentos administrativos e gerenciais" quanto pela própria "estrutura sócio-política destas nações": "[a]s sociedades latino-americanas pós-independência foram, em graus diversos, configuradas por estruturas

\footnotetext{
4 Sobre a gravidade da situação penitenciária na América Latina, ver CARRANZA, Eliás. Cárcel y justicia penal: el modelo de derechos y obligaciones de las Naciones Unidas, y una política integral de seguridade de los habitantes frente el delito. In CARRANZA, Elías (coord.). Criminalidad, cárcel y justicia penal en America Latina y el Caribe. México Siglo XXI Editores, 2009, p. 53-126. César Leal refere-se a um "quadro tenebroso" que se encontra "[v]isível em quase toda América Latina e no Caribe" e "tem sido objeto de denúncias feitas por organismos internacionais de defesa dos direitos humanos e por notáveis penitenciaristas". Cf. LEAL, César Barros. Execução penal na América Latina à luz dos direitos humanos: viagem pelos caminhos da dor. 1 ed. 2a reimpressão. Curitiba: Juruá, 2009, p. 100.

5 CORTE INTERAMERICANA DE DIREITOS HUMANOS. Caso Tibi vs. Equador. Sentença de 7 de setembro de 2004, voto de Sergio García Ramírez, p. 17. Disponível em <http://www.corteidh.or.cr/docs/casos/articulos/ seriec_114_esp.pdf> Acesso em 27 de março de 2018.

6 AGUIRRE, Carlos. Cárcere e sociedade na América Latina: 1800-1940. In MAIA, Clarissa; SÁ NETO, Flávio de; COSTA, Marcos; BRETAS, Marcos Luiz (orgs.). História das prisões no Brasil. v. 1. Rio de Janeiro: Rocco, 2009, p. 40.

AGUIRRE, Carlos. Cárcere e sociedade na América Latina: 1800-1940. In MAIA, Clarissa; SÁ NETO, Flávio de; COSTA, Marcos; BRETAS, Marcos Luiz (orgs.). História das prisões no Brasil. V. 1. Rio de Janeiro: Rocco, 2009, p. 42.
} 
hierárquicas excludentes, racistas e autoritárias que, por trás da fachada de liberalismo e democracia formal, mantiveram formas opressivas de dominação social e controle laboral que incluíam a escravidão, a peonagem e a servidão. Direitos fundamentais de cidadania foram negados a amplos setores da população". E, nesse contexto, "o castigo era visto, geralmente, como um privilégio e um dever em mãos dos grupos dominantes dentro de seus esforços por controlar os grupos turbulentos, degenerados, racialmente inferiores, incapazes de civilizar-se e que, portanto, não mereciam a proteção de seus direitos civis e legais."

Não há razões para acreditar que esse quadro se alterou desde então. Nas últimas décadas foi, ademais, fortemente agravado pelo crescimento vertiginoso da população prisional em todo continente. Entre 2000 e 2015, registra-se um crescimento de $80 \%$ na população prisional da América Central e de $145 \%$ nos países da América do Sul. ${ }^{9}$ Os dados referentes à densidade penitenciária - relação entre o número de vagas e de pessoas presas - são igualmente alarmantes para toda a região, com a maioria dos países apresentando "superpopulação crítica", isto é, com densidades iguais ou superiores a $120 \%{ }^{10}$. Em relatório publicado em 2011 sobre os direitos humanos das pessoas privadas de liberdade nas américas, a Comissão Interamericana de Direitos Humanos, considerando o respeito pelos direitos dos presos um dos maiores desafios para os Estados membros da OEA, documenta no relatório "the existence of serious structural shortcomings that gravely affect non-derogable human rights, such as the right to life and to humane treatment (...)."11

Para vários autores, o sistema prisional que construímos ao longo dos últimos dois séculos ilustra exemplarmente o abismo entre, de um lado, as práticas políticas e institucionais e, de outro, a profusão de normas internacionais, constitucionais, leis, "regras mínimas", "princípios básicos", decretos e regulamentos. Explorando este abismo entre o conjunto normativo e o cotidiano das cárceres na América Latina, Uprimny e Guzmán referem-se à existência de uma "tensión o paradoja: si bien hemos avanzado considerablemente al lograr un marco jurídico que ofrece garantías constitucionales a las

\footnotetext{
8 AGUIRRE, Carlos. Cárcere e sociedade na América Latina: 1800-1940. In MAIA, Clarissa; SÁ NETO, Flávio de; COSTA, Marcos; BRETAS, Marcos Luiz (orgs.). História das prisões no Brasil. V. 1. Rio de Janeiro: Rocco, 2009 , p. 71.

9 No mesmo período, os países europeus viveram um decréscimo de $21 \%$. Vide WALMSLEY, Roy. World Prison Population List. 11th edition. Insitute for Criminal Policy Research, 2015. Disponível em <http://www. prisonstudies.org/sites/default/files/resources/downloads/world_prison_population_list_11th_edition_0. pdf> Acesso em 27 de março de 2018.

10 Os dados de densidade penitenciária copilados por Carranza referem-se ao ano de 2007. Carranza, Cárcel y justicia penal: el modelo de derechos y obligaciones de las Naciones Unidas, y una política integral de seguridade de los habitantes frente el delito, p. 63.

11 INTER-AMERICAN COMISSION OF HUMAN RIGHTS. Report on the Human Rights of Persons Deprived of Liberty in the Americas. 2011, p. 2. Disponível em < http://www.oas.org/en/iachr/pdl/docs/pdf/ppl2011eng. pdf> Acesso em 27 de março de 2018.
} 
personas privadas de la libertad, persiste una precariedad gravísima en el goce efectivo de los derechos fundamentales de la población reclusa del país" ${ }^{12}$.

A questão que surge então é: no contexto prisional latino-americano, como dar concretude a essas garantias fundamentais? Qual o grau de barbárie exigido para incidir a proibição de uma pena cruel? Quais precisam ser as condições de vida em prisão para se reconhecer a agressão à integridade física e moral das pessoas em privação de liberdade?

Refletindo sobre o "conjunto de dispositivos constitucionais [que] procura amenizar o impacto da prisão nos direitos fundamentais do acusado", Dimoulis indica que essas normas desenvolvem efeitos em três direções: "impõem ao legislador a criação de normas concretizadoras", "endereçam mandamentos diretos aos órgãos estatais que atuam nos casos de prisão" e permitem a verificação da "constitucionalidade de normas legais sobre o tratamento dos presos". De acordo com Dimoulis, o conjunto de normas estabelecendo proibições - de penas cruéis, de agressões à integridade física, maus-tratos, etc. - gera ao menos três tipos de efeitos: impõem ao legislador a criação de normas concretizadoras, permitem o controle de constitucionalidade da produção legislativa e, dirigidas diretamente aos órgãos estatais que atuam no campo prisional, podem gerar múltiplas formas de responsabilização dos agentes implicados ${ }^{13}$. Nos dois últimos casos, a concretização das normas depende diretamente da atuação dos órgãos jurisdicionais.

O"estado de coisas inconstitucional" vem acrescentar a esse rol uma quarta possibilidade de impulsionar a concretização das normas que garantem os direitos fundamentais dos acusados e das pessoas em privação de liberdade. Não se trata aqui de questionar a constitucionalidade de leis ou de responsabilizar agentes públicos pelo descumprimento sistemático de um conjunto de normas, mas sim reconhecer a gravidade e a amplitude das violações de direitos, a responsabilidade partilhada por vários entes estatais e a necessidade de implementação de estratégias complexas, de curto, médio e longo prazo, para cessar essas violações. Às experiências colombiana e brasileira que buscam dar concretude a esse instituto dedica-se a próxima seção.

\footnotetext{
12 YEPES, Rodrigo Uprimny. GUZMÁN, Diana Esther. Las Cárceles en Colombia: entre una Jurisprudencia Avanzada y un Estado de Cosas Inconstitucionales. In: SEGURA, Juan David Posada (coord.). III Simposio Internacional Penitenciario y de Derechos Humanos. Medellín: Universidad de San Buena Ventura, 2010, p. 145-164. No mesmo sentido, "(...) sabemos que no todo el derecho coincide con la realidad, y la realidad penitenciaria suele ser el ejemplo más grave de esa discrepancia" Carranza, CARRANZA, Cárcel y justicia penal: el modelo de derechos y obligaciones de las Naciones Unidas, y una política integral de seguridade de los habitantes frente el delito. In CARRANZA, Elías (coord.). Criminalidad, cárcel y justicia penal en America Latina y el Caribe. México: Siglo XXI Editores, 2009, p. 61. Ver, ainda, Leal ao discorrer sobre o "divórcio entre as normas e a realidade" no campo prisional: LEAL, César Barros. Execução penal na América Latina à luz dos direitos humanos: viagem pelos caminhos da dor. 1 ed. $2^{\text {a }}$ reimpressão. Curitiba: Juruá, 2009, p. 117.

13 DIMOULIS, Dimitri. Direito penal constitucional: garantismo na perspectiva do pragmatismo jurídico-político. Belo Horizonte: Arraes, 2016, p. 52-54.
} 


\section{AS DECISÕES NA COLÔMBIA E NO BRASIL}

\section{O "estado de coisas inconstitucional" constitui uma figura desenvolvida pela Su-} prema Corte Colombiana em 1997 (SU-559) ${ }^{14}$ que vem sendo utilizada nos casos de violações de direitos fundamentais que compartilham três características: (i) são "o resultado de uma causa estrutural ou histórica" que (ii) "não pode ser atribuída a um único ente mas ao Estado em seu conjunto" e que (iii) "exige a adoção de medidas de longo prazo"15. Desde então, diversas violações sistemáticas de direitos fundamentais foram analisadas pela Corte Colombiana à luz do "estado de coisas inconstitucional", permitindo que a Corte ampliasse e sofisticasse seu âmbito de atuação nesses casos. ${ }^{16}$ Percebida como "um dos aportes fundamentais do constitucionalismo colombiano à jurisprudência e à discussão internacional sobre a proteção dos direitos humanos"17, a figura do "estado de coisas inconstitucional" vem sendo intensamente debatida no Brasil. ${ }^{18}$

14 COLOMBIA. Corte Constitucional. Sentencia 559/97. Bogotá, 6.11.1997. Disponível em < http://www.corteconstitucional.gov.co/relatoria/1997/SU559-97.htm> Acesso em 27 de março de 2018.

15 ARIZA, Libardo José. La prisión ideal: intervención judicial y reforma del sistema penitenciario en Colombia. In BONILLA, Daniel; ITURRALDE, Manuel (eds.). Hacia un nuevo derecho constitucional. Bogotá: Ediciones Uniandes, 2005, p. 283-328. . A caracterização dessa figura aparece em termos um pouco distintos em Garavito: "afetam um número amplo de pessoas", "envolvem várias entidades estatais consideradas responsáveis por falhas sistemáticas de políticas públicas" e"implicam ordens de execução complexas, mediantes as quais o juiz instrui várias entidades públicas a empreender ações coordenadas para proteger toda a população afetada". GARAVITO, César Rodríguez. Más allá del desplazamiento, o cómo superar un estado de cosas inconstitucional. GARAVITO, César Rodríguez (coord.). Más allá del desplazamiento, o cómo superar un estado de cosas inconstitucional. Bogotá: Universidad de los Andes, Facultad de Derecho, Ediciones Uniandes, 2009, p. 434-493.

16 Páez sustenta que a ideia do $\mathrm{ECl}$ é mais um produto do neoconstitucionalismo. Ademais, ele sugere uma definição funcional do $\mathrm{ECl}$ no contexto judicial colombiano: "La doctrina del ECI se instituyó como una solución que adopta el juez constitucional ante la constatación de que las causas de una desprotección generalizada de derechos fundamentales obedece a causas estructurales del Estado, frente a lo cual dicta órdenes a las autoridades administrativas tendientes a dar remedio a la situación inconstitucional y que obedecerán al entendimiento que el tribunal tenga sobre las fallidas o inexistentes políticas públicas que debería aplicarse para garantizar los derechos fundamentales violados.". Cf. PÁEZ, Nicolás Augusto Romero. La doctrina del estado de cosas inconstitucional en Colombia: novedades del neoconstitucionalismo y "la inconstitucionalidad de la realidad". Derecho Público Iberoamericano, Santiago, n. 1, p. 243-264, out. 2012, p. 243-244.

17 GARAVITO, César Rodríguez. Más allá del desplazamiento, o cómo superar un estado de cosas inconstitucional. GARAVITO, César Rodríguez (coord.). Más allá del desplazamiento, o cómo superar un estado de cosas inconstitucional. Bogotá: Universidad de los Andes, Facultad de Derecho, Ediciones Uniandes, 2009, p. 435.

18 Para José Rodrigo Rodriguez, o "estado de coisas surreal de nossas prisões, aliás, é típico das sociedades latino-americanas, em especial da brasileira", sendo que a decisão cautelar do STF foi uma "benvinda inovação na maneira pela qual os poderes do Estado se relacionam entre si". RODRIGUEZ, José Rodrigo. Estado de Coisas Surreal. JOTA. 25 de setembro de 2015. Disponível em <https://www.jota.info/opiniao-e-analise/artigos/ estado-de-coisas-surreal-25092015> Acesso em 27 de março de 2018. Trata-se de uma resposta contundente ao artigo de Raffaele De Giorgio, José Eduardo Faria e Celso Campilongo, que discorre sobre os riscos da ideia de "estado de coisas inconstitucional" DE GIORGI, Raffaele; FARIA, José Eduardo; CAMPILONGO, Celso. Estado de Coisas Inconstitucional. O Estado de São Paulo. 19 de setembro de 2015. Disponível em <http://opiniao. estadao.com.br/noticias/geral,estado-de-coisas-inconstitucional,10000000043> Acesso em 27 de março de 2018. Ver, ainda, LAGE, Daniel; BRUGGER, Andrey. Estado de coisas inconstitucional: legitimidade, utilização e considerações. Revista Publicum, Rio de Janeiro, vol. 3, n. 2, p. 193-240, 2017. 
Diante dos objetivos desse texto, essa seção buscará apresentar e comparar alguns aspectos das decisões proferidas pela Suprema Corte Colombiana e pelo Supremo Tribunal Federal Brasileiro ${ }^{19}$. Em que pesem as notáveis diferenças entre as duas decisões, ambas coincidem em declarar o "estado de coisas inconstitucional" do sistema prisional e a dirigir as intervenções para alteração deste quadro tão somente para o sistema político, em particular, para o poder executivo. Especialmente no caso brasileiro, os pedidos dos subscritores da ação que buscavam enfrentar a cultura do encarceramento no interior do sistema de direito criminal, foram negados. $\mathrm{O}$ mesmo ocorreu em nova decisão da Suprema Corte Colombiana em que a ação buscava também medidas de desencarceramento.

As diferenças entre as decisões dos dois países são de várias ordens. ${ }^{20}$ Em primeiro lugar, a decisão colombiana (T-153/1998) ${ }^{21}$ já pode ser observada a partir do que pode alcançar: há documentos governamentais relatando as "ações de cumprimento da sentença", bem como debates e estudos acadêmicos sobre seu significado, seu aporte e seus limites. No Brasil, diferentemente, apenas a medida cautelar da arguição de descumprimento de preceito fundamental (ADPF 347/2015) ${ }^{22}$ foi julgada e, até a conclusão desse texto, o mérito da ação ainda não havia sido submetido a julgamento. Em virtude disso, esse texto atém-se a observar o modo como as Cortes Constitucionais recepcionaram a questão da violação sistemática dos direitos dos presos e sobre o que decidiram intervir (ainda que cautelarmente, no caso brasileiro). No caso colombiano, a permanência do "estado de coisas inconstitucional", apesar do cumprimento de grande parte das ordens impostas pela sentença, ensejou novas ações, julgadas pela Suprema

19 A comparação entre as duas experiências é abordada em detalhe, porém com outro enfoque, em SANTOS, Helena; Vieira, José; DAMASCENO, Luana; CHAGAS, Tainá. Estado de coisas inconstitucional: um estudo sobre os casos colombiano e brasileiro. Quaestio luris. Rio de Janeiro, vol. 08, n. 04, p. 2595-2612, 2015.

20 Sobre o contexto colombiano, conferir: GARAVITO, César Rodríguez; FRANCO, Diana. Cortes y Cambio Social: como la Corte Constitucional transformó el desplazamiento forzado en Colombia. Bogotá: Centro de Estudios de Derecho, Justicia y Sociedad, 2010.

21 COLOMBIA. Corte Constitucional. Sentencia de Tutela n. 153/98. Magistrado Responsável: Eduardo Cifuentes Muñoz. Bogotá, 28 de abril de 1998. Disponível em <https://app.vlex.com/\#vid/43561621> acesso em 27 de março de 2018. Esta decisão será indicada, em diante, como T-153.

22 De acordo com Soares, esta ADPF teve como embrião científico a Clínica de Direitos Fundamentais da Faculdade de Direito da Universidade do Estado do Rio de Janeiro (UERJ) e, em especial, a tese de doutorado de Carlos Alexandre de Azevedo Campos, sob orientação de Daniel Sarmento, "Da Inconstitucionalidade por Omissão ao Estado de Coisas Inconstitucional". "Assim, sedimentada a mencionada tese, a citada Clínica sustentou a existência de violações sistemáticas dos direitos humanos da população carcerária brasileira, vez que visualizou, diante da jurisprudência colombiana, a possível aplicabilidade do Estado de Coisas Inconstitucional (ECI) no ordenamento jurídico nacional [...] a atuação do PSOL na propositura da ADPF 347 se deu em decorrência da falta de legitimidade jurídica da Clínica de Direitos Fundamentais da Faculdade de Direito da Universidade do Estado do Rio de Janeiro (UERJ) para ajuizá-la". SOARES, Renata Araújo. O Estado de coisas inconstitucional e a calamidade do sistema penitenciário: diretrizes constitucionais para uma política transversal de segurança pública. 152 pp. Dissertação (Mestrado). Programa de Pós-graduação em Direito: Universidade Federal do Rio Grande do Norte. 2018. Disponível em: https://repositorio.ufrn.br/jspui/ bitstream/123456789/26696/1/Estadocoisasinconstitucional_Soares_2018.pdf Acesso em: 07 jul. 2020. 
Corte em 2013 e 2015, em relação as quais conta-se ainda com escasso material de análise ${ }^{23}$.

As decisões das Supremas Cortes Colombiana e Brasileira, em 1998 e em 2015, reconhecem o "estado de coisas inconstitucional" dos respectivos sistemas penitenciários. Apoiam-se em relatórios, documentos, dados sobre a relação entre número de presos e vagas, bem como em inspeções realizadas por autoridades públicas. As decisões ilustram o que adjetivam como "absolutamente subumanas", "uma vergonha para o Estado", "situações infernais de superlotação" 24 e, ainda, "situação vexaminosa" e "assustadora" 25 com descrições sobre as formas de violação dos direitos dos presos. A decisão colombiana menciona prisões em que as pessoas dormem no chão, inclusive nos banheiros; celas construídas para abrigar uma pessoa e que contavam com 3 a 6 pessoas, a depender do pavilhão; celas de madeira e papelão, construídas pelas próprias pessoas em privação de liberdade, em que mal se pode respirar diante do sufocante calor. A decisão brasileira agrega a esta narrativa a ausência de "condições adequadas para a existência humana": celas imundas, sem iluminação e ventilação, áreas de banho e sol com esgotos abertos, ausência de acesso a água, lugares em que a comida é servida em sacos plásticos, além da ausência de fornecimento de material de higiene básica. Sem acesso à educação, trabalho ou qualquer forma de ocupação, "convivem com as barbáries promovidas contra si": "massacres, homicídios, violências sexuais, decapitação, estripação e esquartejamento", e "tortura policial, espancamentos, estrangulamentos, choques elétricos, tiros com bala de borracha". Descreve também as violações específicas aos direitos das pessoas trans, a ausência de separação das pessoas por idade, tipo de delito e natureza da prisão (cautelar ou definitiva), bem como o número insuficiente e o despreparo dos agentes penitenciários. ${ }^{26}$ Como a Corte Colombiana, conclui que o "quadro não é exclusivo desse ou daquele presídio", mostrando-se similar em diferentes regiões do país.

As decisões elencam também as normas constitucionais, bem como as internacionais, penais, processuais e penitenciárias que são sistematicamente transgredidas por esse estado de coisas. A Corte Colombiana descreve esse quadro normativo, bem

\footnotetext{
23 Agradeço ao Professor Libardo José Ariza por chamar minha atenção para estas ações, facilitar acesso aos materiais disponíveis e fornecer esclarecimentos essenciais à compreensão sobre as duas novas sentenças. Por prudência, não me atrevo a analisar diretamente as decisões colombianas, apoio-me, nesse texto, nas reflexões produzidas pelo Professor Ariza e outros juristas colombianos que se debruçaram, em especial, sobre a sentença de 1998.

24 COLOMBIA. Corte Constitucional. Sentencia de Tutela n. 153/98. Magistrado Responsável: Eduardo Cifuentes Muñoz. Bogotá, 28 de abril de 1998, p. 37.

25 BRASIL. Supremo Tribunal Federal. Acórdão. Arguição de Descumprimento de Preceito Fundamental (ADPF) n³47. Relator: Min. Marco Aurélio. Brasília, 19 fev. 2016, p. 22 e 26.

26 BRASIL. Supremo Tribunal Federal. Acórdão. Arguição de Descumprimento de Preceito Fundamental (ADPF) n³47. Relator: Min. Marco Aurélio. Brasília, 19 fev. 2016, p. 25-26.
} 
como a jurisprudência da Corte, como "letra morta". 27 As narrativas, em ambos os casos, concluem afastando qualquer elemento de novidade. O quadro é amplamente conhecido pelo poder público e pela população. ${ }^{28}$

As decisões das Supremas Cortes Colombiana e Brasileira, em 1998 e em 2015, reconhecem o "estado de coisas inconstitucional" dos respectivos sistemas penitenciários. Apoiam-se em relatórios, documentos, dados sobre a relação entre número de presos e vagas, bem como em inspeções realizadas por autoridades públicas. As decisões ilustram o que adjetivam como "absolutamente subumanas", "uma vergonha para o Estado", "situações infernais de superlotação"29 e, ainda, "situação vexaminosa" e "assustadora" ${ }^{\prime 30}$ com descrições sobre as formas de violação dos direitos dos presos. A decisão colombiana menciona prisões em que as pessoas dormem no chão, inclusive nos banheiros; celas construídas para abrigar uma pessoa e que contavam com 3 a 6 pessoas, a depender do pavilhão; celas de madeira e papelão, construídas pelas próprias pessoas em privação de liberdade, em que mal se pode respirar diante do sufocante calor. A decisão brasileira agrega a esta narrativa a ausência de "condições adequadas para a existência humana": celas imundas, sem iluminação e ventilação, áreas de banho e sol com esgotos abertos, ausência de acesso a água, lugares em que a comida é servida em sacos plásticos, além da ausência de fornecimento de material de higiene básica. Sem acesso à educação, trabalho ou qualquer forma de ocupação, "convivem com as barbáries promovidas contra si": "massacres, homicídios, violências sexuais, decapitação, estripação e esquartejamento", e "tortura policial, espancamentos, estrangulamentos, choques elétricos, tiros com bala de borracha". Descreve também as violações especíicas aos direitos das pessoas trans, a ausência de separação das pessoas por idade, tipo de delito e natureza da prisão (cautelar ou definitiva), bem como o número insuficiente e o despreparo dos agentes penitenciários ${ }^{31}$. Como a Corte Colombiana, conclui que o "quadro não é exclusivo desse ou daquele presídio", mostrando-se similar em diferentes regiões do país.

As decisões elencam também as normas constitucionais, bem como as internacionais, penais, processuais e penitenciárias que são sistematicamente transgredidas por esse estado de coisas. A Corte Colombiana descreve esse quadro normativo, bem

27 COLOMBIA. Corte Constitucional. Sentencia de Tutela n. 153/98. Magistrado Responsável: Eduardo Cifuentes Muñoz. Bogotá, 28 de abril de 1998, p. 70.

28 COLOMBIA. Corte Constitucional. Sentencia de Tutela n. 153/98. Magistrado Responsável: Eduardo Cifuentes Muñoz. Bogotá, 28 de abril de 1998, p. 37.

29 COLOMBIA. Corte Constitucional. Sentencia de Tutela n. 153/98. Magistrado Responsável: Eduardo Cifuentes Muñoz. Bogotá, 28 de abril de 1998, p. 37.

30 BRASIL. Supremo Tribunal Federal. Acórdão. Arguição de Descumprimento de Preceito Fundamental (ADPF) n³47. Relator: Min. Marco Aurélio. Brasília, 19 fev. 2016, p. 22 e 26.

31 BRASIL. Supremo Tribunal Federal. Acórdão. Arguição de Descumprimento de Preceito Fundamental (ADPF) n³47. Relator: Min. Marco Aurélio. Brasília, 19 fev. 2016, p. 25-26. 
como a jurisprudência da Corte, como "letra morta" ${ }^{\prime 32}$. As narrativas, em ambos os casos, concluem afastando qualquer elemento de novidade. O quadro é amplamente conhecido pelo poder público e pela população ${ }^{33}$.

As decisões enfatizam também que a violação sistemática dos direitos dos presos está diretamente associada à "inação das autoridades" que "apesar de muitas solicitações e críticas" não desenvolvem qualquer "política oficial para modificar a raiz da gravíssima situação carcerária do país" ${ }^{\prime 34}$. O voto do Ministro Marco Aurélio discorre longamente sobre a "responsabilidade do poder público", indicando expressamente que essa responsabilidade deve ser atribuída aos três poderes, tanto na esfera federal quanto estadual. "Faltam sensibilidade legislativa e motivação política do Executivo", diz o Ministro ${ }^{35}$. Ao lado do problema de "formulação e implementação de políticas públicas", mencionado pela decisão colombiana, o Ministro Marco Aurélio acrescenta problemas de "interpretação e aplicação da lei penal"36. Mais especificamente, em relação à responsabilidade do poder judiciário, o Ministro menciona o elevado número de presos provisórios, que ao final são absolvidos ou condenados a sanções não prisionais, e de pessoas que permanecem presas após o término do tempo determinado na sentença. Diante disso, conclui que o "conjunto de soluções [...] deve envolver a atuação coordenada e mutuamente complementar do Legislativo, do Executivo e do Judiciário, dos diferentes níveis federativos" ${ }^{\prime \prime 37}$. De modo bastante mais tímido, pelas razões expostas a seguir, a decisão colombiana indica também que o problema não está apenas nas mãos do executivo, especialmente do Ministério da Justiça, e que portanto "distintas

32 COLOMBIA. Corte Constitucional. Sentencia de Tutela n. 153/98. Magistrado Responsável: Eduardo Cifuentes Muñoz. Bogotá, 28 de abril de 1998, p. 70.

33 COLOMBIA. Corte Constitucional. Sentencia de Tutela n. 153/98. Magistrado Responsável: Eduardo Cifuentes Muñoz. Bogotá, 28 de abril de 1998, p. 37.

34 COLOMBIA. Corte Constitucional. Sentencia de Tutela n. 153/98. Magistrado Responsável: Eduardo Cifuentes Muñoz. Bogotá, 28 de abril de 1998, p. 72.

35 BRASIL. Supremo Tribunal Federal. Acórdão. Arguição de Descumprimento de Preceito Fundamental (ADPF) n³47. Relator: Min. Marco Aurélio. Brasília, 19 fev. 2016, p. 27.

36 BRASIL. Supremo Tribunal Federal. Acórdão. Arguição de Descumprimento de Preceito Fundamental (ADPF) n³47. Relator: Min. Marco Aurélio. Brasília, 19 fev. 2016, p. 26.

37 Em comentário sobre a decisão, Mendes e Branco argumentam em sentido semelhante, considerando que o STF teria decidido a partir da identificação de "uma falha estrutural comum aos três Poderes no enfrentamento do problema carcerário". Os autores legitimam tal tipo de decisão, dado que não violaria a separação de poderes, pelo contrário, "o desrespeito a um direito fundamental pela falta de sua concretização por órgãos estranhos ao Judiciário autoriza, em casos de mais aguda gravidade, que o juiz imponha as providências concretas, estimadas necessárias para que a omissão não agrave o dano que gera. Determinação dessa sorte não há de ser censurada como hostil à separação de Poderes, nem é obstada pela defesa da reserva do possível". MENDES, Gilmar Ferreira; BRANCO, Paulo Gustavo Gonet. Curso de Direito Constitucional. 14 ed. São Paulo: Saraiva, 2019. 
áreas e órgãos do Poder Público" serão requeridas a "tomar as medidas adequadas para a solução do problema" ${ }^{38}$.

A decisão colombiana, diferentemente da brasileira, organiza-se sobretudo ao redor do problema da superlotação dos presídios. Ainda que diversos outros aspectos relacionados às péssimas condições de vida em prisão, império da violência, carência de oportunidades e meios para ressocialização sejam mencionados, a superlotação é o objeto principal dos pedidos, e o centro da argumentação desenvolvida pela Corte. É a partir do problema da superpopulação que a Corte faz derivar a violação de todos direitos dos presos: direito à dignidade, a não receber tratamento ou penas cruéis, inumanas ou degradantes, direito à vida e à integridade física, direito à família (diante dos obstáculos às visitas), direito à saúde, ao trabalho, à educação e o direito à presunção de inocência, violado pela ausência de separação entre condenados e provisórios ${ }^{39}$. Diante disso, a Corte determina, em primeiro lugar, a notificação das autoridades máximas, dos três poderes, sobre o estado de coisas inconstitucional das prisões colombianas. Determina também a órgãos do poder executivo a elaboração de um plano de "construção e reforma prisional" e ao governo que garanta previsão orçamentária para tanto. O plano deve ser executado em 4 anos e, nesse mesmo período, deve se concluir a separação completa dos presos condenados e provisórios. Outros pedidos mais específicos foram também concedidos pela Corte, direcionados à separação dos presos da Força Pública, a solucionar o problema da falta de pessoal especializado, a criação de centros de detenção pelo s governos estadual e municipal, bem como à investigação, por parte do Conselho Superior da Magistratura, sobre a ausência de juízes de execução suficientes em determinadas prisões. A decisão conclui ordenando ao Presidente da República que, "enquanto se executam as obras carcerárias ordenadas [...] tomem as medidas necessárias para garantir a ordem pública e os direitos fundamentais dos internos" ${ }^{40}$, sem especificar quais seriam ou deveriam ser essas medidas.

É possível dizer, portanto, que esta primeira decisão que declara o estado de coisas inconstitucional das prisões colombianas restringe-se a exigir a elaboração de um plano para a construção e reforma dos presídios, com vistas a resolver a questão do déficit de vagas. Convoca, sobretudo o poder executivo, a atuar no enfrentamento de problemas relacionados à separação dos presos e aos agentes prisionais; mas não se pronuncia sobre o modo como o próprio Poder Judiciário poderia atuar para reduzir o número de pessoas em privação de liberdade. Sem uma intervenção sobre

38 COLOMBIA. Corte Constitucional. Sentencia de Tutela n. 153/98. Magistrado Responsável: Eduardo Cifuentes Muñoz. Bogotá, 28 de abril de 1998, p. 74.

39 COLOMBIA. Corte Constitucional. Sentencia de Tutela n. 153/98. Magistrado Responsável: Eduardo Cifuentes Muñoz. Bogotá, 28 de abril de 1998, p. 73.

40 COLOMBIA. Corte Constitucional. Sentencia de Tutela n. 153/98. Magistrado Responsável: Eduardo Cifuentes Muñoz. Bogotá, 28 de abril de 1998, p. 79-80. 
a atuação do Poder Judiciário, as vagas obtidas com o plano de construção podem rapidamente se tornar insuficientes, como de fato ocorreu no caso colombiano. Esta questão será abordada a seguir, mas antes abordaremos a decisão brasileira que, apesar de ter sido provocada a intervir sobre a atuação do Judiciário, não acatou os pedidos dessa natureza.

Dos oito pedidos cautelares formulados na Arguição de Descumprimento de Preceito Fundamental, seis dirigem-se diretamente ao poder judiciário e, particularmente, ao sistema de direito criminal. Para os autores da ação, equacionar o gravíssimo problema prisional no país exige não apenas a construção de novas vagas - ao redor de 200 mil -, mas a interpretação das normas constitucionais em matéria de aplicação e execução de penas à luz das "dramáticas condições do sistema prisional do país"41. Os pedidos cautelares demandam que os juízes (a) motivem expressamente as razões que impedem a concessão de medidas cautelares não prisionais; (b) realizem audiências de custódia em até 24 horas após a prisão; (c) considerem o quadro dramático do sistema prisional na concessão de cautelares, na aplicação e na execução da pena; (d) apliquem, "sempre que for viável", penas alternativas à prisão, com vistas a preservar a proporcionalidade e a humanidade da pena; (e) abrandem os requisitos temporais para fruição de benefícios e direitos dos presos e (f) reduzam o tempo de prisão a ser cumprido, quando as condições de cumprimento são significativamente mais severas do que as impostas na sentença. Os dois últimos pedidos, não direcionados ao Judiciário, dirigem-se à (g) realização de "mutirões carcerários", pelo Conselho Nacional de Justiça para revisar os processos de execução com vistas a adequá-los aos pedidos 'e' e 'f', acima e (h) a liberação de verbas do Fundo Penitenciário Nacional (Funpen) para os governos estaduais utilizarem na construção, reforma e aprimoramento dos sistemas penitenciários.

Entre os pedidos direcionados ao poder judiciário, apenas a determinação de realização de audiências de custódia (item b) foi deferida pela Corte. Os dois pedidos que poderiam gerar o desencarceramento ( $e$ e $f$ ) foram negados por unanimidade (pedido $f$ ) e por nove votos a 1 (pedido $e$ ). Os demais ( $a, c$ e $d$ ) foram negados por maioria apertada (seis votos contra quatro). O último pedido, relacionado à liberação de verbas do Funpen também foi concedido.

O pedido definitivo da ADPF, que ainda está pendente, além de confirmar as medidas cautelares acima, requer a elaboração de um plano nacional, pelo Governo Federal, visando à superação do estado de coisas inconstitucional. Com propostas e metas específicas, bem como com a previsão dos recursos orçamentários necessários, os autores da ação demandam que o plano seja submetido a amplo debate público

41 BRASIL. Supremo Tribunal Federal. Petição Inicial na Arguição de Descumprimento de Preceito Fundamental (ADPF) $\mathbf{n}^{\circ}$ 347. Rio de Janeiro, 26 de maio de 2015, p. 68. Disponível em: <http://www.jota.info/ wp-content/uploads/2015/05/ADPF-347.pdf>. Acesso em: 26 mar. 2018. 
antes de ser homologado pelo Supremo Tribunal Federal. Demandam também que, após a elaboração do plano nacional, seja exigido dos governos estaduais a elaboração de planos estaduais, a serem também debatidos publicamente e deliberados pelo STF. Por fim, os autores demandam que a implementação do plano seja monitorada pelo STF "em processo público e transparente, aberto à participação colaborativa da sociedade civil".42

As duas decisões coincidem em alocar a questão prisional como uma demanda de "minorias", em relação às quais as cortes constitucionais têm a "missão" de defender ${ }^{43}$. A decisão brasileira destaca, neste ponto, que se trata de "uma pauta impopular, envolvendo direitos de um grupo de pessoas não simplesmente estigmatizado, e sim cuja dignidade humana é tida por muitos como perdida, ante o cometimento de crimes"44. E mesmo em face dessa "missão", e do pleno reconhecimento do estado de coisas inconstitucional, as decisões não se atreveram a reconhecer as normas constitucionais que proíbem as penas cruéis, o tratamento desumano ou degradante e que garantem a integridade física e moral das pessoas em privação de liberdade. Como se viu, até o momento não foram tomadas medidas que implicassem em alterações concretas das condições de vida das milhares de pessoas que vivem sob o "estado de coisas inconstitucional".

No caso colombiano, Ariza aponta que a sentença buscou resolver o problema das prisões por intermédio da construção e reforma, em um período de 4 anos, sem adotar qualquer ordem que pudesse remediar os problemas dos indivíduos que ali estavam enquanto o plano era implementado. E se pergunta "como é possível que ao mesmo tempo se reconheça que a prisão viola direitos fundamentais e se exija que os presos permaneçam estoicamente nela?"45 A mesma indagação vale para a decisão brasileira no pedido cautelar. Para Ariza, essa postura paradoxal da Corte Colombiana é possível graças à definição da realidade carcerária como um problema histórico "que permite um uso indolente do tempo vital das pessoas que estão em prisão"46. De acordo com o balanço do autor, sete anos após a sentença, a resposta da Corte se traduziu

\footnotetext{
42 BRASIL. Supremo Tribunal Federal. Petição Inicial na Arguição de Descumprimento de Preceito Fundamental (ADPF) n³47. Rio de Janeiro, 26 de maio de 2015, p. 72.

43 BRASIL. Supremo Tribunal Federal. Acórdão. Arguição de Descumprimento de Preceito Fundamental (ADPF) n³47. Relator: Min. Marco Aurélio. Brasília, 19 fev. 2016, p. 21.

44 BRASIL. Supremo Tribunal Federal. Acórdão. Arguição de Descumprimento de Preceito Fundamental (ADPF) n 347. Relator: Min. Marco Aurélio. Brasília, 19 fev. 2016, p. 21.

45 ARIZA, Libardo José. La prisión ideal: intervención judicial y reforma del sistema penitenciario en Colombia. In BONILLA, Daniel; ITURRALDE, Manuel (eds.). Hacia un nuevo derecho constitucional. Bogotá: Ediciones Uniandes, 2005, p. 312 (tradução livre).

46 ARIZA, Libardo José. La prisión ideal: intervención judicial y reforma del sistema penitenciario en Colombia. In BONILLA, Daniel; ITURRALDE, Manuel (eds.). Hacia un nuevo derecho constitucional. Bogotá: Ediciones Uniandes, 2005, p. 313 (tradução livre).
} 
em aumento significativo do sistema penitenciário, com a criação de novas vagas, "sem que tenha se produzido uma modificação paralela das condições de reclusão" ${ }^{47}$.

A partir das taxas de superlotação colombianas entre 1997 e 2009, Uprimny e Guzmán observam uma redução importante nos anos 2000 e 2001 - em que a taxa esteve ao redor de $16 \%$, em face dos $45 \%$ do ano de 1997. Para os autores, a diminuição "parece dever-se às ações empreendidas pelo Estado" em cumprimento à sentença 153/1998. No entanto, afirmam os autores, "logo voltaram a endurecer as políticas punitivas", ocasionando novo aumento na taxa que em 2009 alcançou quase $39 \%{ }^{48}$. Isto é, aumentaram-se as vagas mas não no mesmo ritmo de aumento do número de pessoas presas. Não por outra razão, a Corte Colombiana voltou a declarar o estado de coisas inconstitucional das prisões do país em 2013 e 2015.

No Brasil, o julgamento definitivo da ADPF 347 coloca o STF diante da oportunidade de, para além de reconhecer a calamidade do quadro fático, dar concretude e extrair consequências das normas constitucionais que expressamente proíbem esse estado de coisas. Para tanto, como indicam os subscritores da ação, a decisão precisaria reconhecer a responsabilidade do próprio poder judiciário sobre esse estado de coisas, e dirigir-se às magistradas e magistrados que atuam nas audiências de custódia, nas varas criminais e nas varas de execução.

\section{AS FISSURAS NO MODELO CRISTALIZADO DE SEPARAÇÃO DE PODERES}

A breve síntese das decisões sobre o estado de coisas inconstitucional no Brasil e na Colômbia oferece pontos importantes para a reflexão proposta aqui. Em primeiro lugar, a experiência colombiana permite observar que a atribuição de responsabilidade ao poder executivo determinando a criação de novas vagas sanou o déficit, temporariamente, mas não alterou as condições de vida das pessoas em prisão e tampouco a engrenagem de encarceramento que seguiu em expansão. A decisão da Suprema Corte e suas implicações concretas no sistema prisional colombiano colocam diretamente em questão um dos componentes centrais do modelo cristalizado de separação de poderes ${ }^{49}$, sintetizado na epígrafe deste texto: "o problema carcerário é puramente

47 ARIZA, Libardo José. La prisión ideal: intervención judicial y reforma del sistema penitenciario en Colombia. In BONILLA, Daniel; ITURRALDE, Manuel (eds.). Hacia un nuevo derecho constitucional. Bogotá: Ediciones Uniandes, 2005, p. 284 (tradução livre).

48 YEPES, Rodrigo Uprimny. GUZMÁN, Diana Esther. Las Cárceles en Colombia: entre una Jurisprudencia Avanzada y un Estado de Cosas Inconstitucionales. In: SEGURA, Juan David Posada (coord.). III Simposio Internacional Penitenciario y de Derechos Humanos. Medellín: Universidad de San Buena Ventura, 2010, p. 157.

49 Sobre o caso da Colômbia, Bustamante Peña considera, por outro lado, que a posição daquele Tribunal não configura "ativismo judicial", mas "faz parte da consolidação do Estado de direito e da separação de poderes, que se vê complementada pela colaboração harmônica dos poderes públicos, neste caso, através de uma declaração de imobilidade institucional, que pretende entregar ferramentas e pressão judicial sobre o Governo 
de investimento do estado". Não é. O investimento pode efetivamente ocorrer, as vagas podem efetivamente ser criadas, e o problema permanece.

No caso do Brasil, os autores da ação buscaram justamente provocar uma fissura nesse modelo, convocando o poder judiciário a assumir responsabilidade pelo problema carcerário no âmbito das decisões que são tomadas cotidianamente pelo sistema de justiça criminal ${ }^{50}$. Os pedidos foram negados cautelarmente mas ofereceram um rol de possibilidades, muito concretas, para promover o desencarceramento. E o fizeram, sobretudo, instando o judiciário a pautar o processo decisório sobre as penas (cautelares ou definitivas) nas características do caso concreto ${ }^{51}$.

Conforme a análise proposta aqui, essa convocação ao judiciário para decidir em função do caso concreto opera-se, na ADPF 347, por dois caminhos. O primeiro, bastante conhecido mas muito fragilmente implementado, refere-se à "individualização da pena", isto é, à plena consideração da biografia da pessoa no momento da tomada da decisão. Os pedidos $a$ e $b$, sobre a motivação expressa para a não concessão de medidas cautelares não prisionais e a implementação das audiências de custódia, instam o judiciário a chamar para si a responsabilidade de conhecer a pessoa presa em flagrante e, diante dela, sendo o caso de conversão do flagrante, pensar primeiro na aplicação de cautelares não prisionais. $E$, havendo impedimento em sua utilização, expressá-lo integralmente na decisão. $O$ pedido $d$, igualmente, sobre a aplicação de penas alternativas à prisão, coloca em relevo a necessidade de observar a proporcionalidade da pena,

para sair da crise". BUSTAMANTE PEÑA, Gabriel. Estado de cosas inconstitucional y políticas públicas. 2011. Maestría (Estudios Políticos) - Pontificia Universidad Javeriana, Bogotá, D.C., 2011. Disponível em: http:// participaz. com/images/pdf/Capitulo6/estado_de_cosas_insconstitucional.pdf . Acesso em: 01 jun. 2020. (tradução livre).

50 Como sustenta a tese de Campos que se atrela à própria proposição desta ADPF: "Não se trata da inércia de uma única autoridade pública, nem de uma única unidade federativa, e sim do funcionamento deficiente do Estado como um todo que tem resultado na violação desses direitos. Os poderes, órgãos e entidades federais e estaduais, em conjunto, vem se mantendo incapazes e manifestado verdadeira falta de vontade política em buscar superar ou reduzir o quadro objetivo de inconstitucionalidade. Falta sensibilidade legislativa quanto ao tema da criminalização das drogas, razão maior das prisões. O próprio Judiciário tem contribuído com o excesso de prisões provisórias, mostrando falta de critérios adequados para tanto. Falta estrutura de apoio judiciário aos presos". CAMPOS, Carlos Alexandre de Azevedo. Da Inconstitucionalidade por Omissão ao Estado de Coisas Inconstitucional. 248 pp. Tese (Doutorado). Programa de Pós-graduação em Direito: Universidade Estadual do Rio de Janeiro. 2015. Disponível em: http://www.bdtd.uerj.br/tde_busca/arquivo.php?codArquivo=8742. Acesso em: 07 jul. 2020.

51 Saliente-se que a utilização de uma ideia concebida fora do Brasil atraiu críticas concernentes à sua capacidade de mudar a situação carcerária brasileira. Nesse sentido: "Do ponto de vista dogmático, não é tarefa simples explicar a inserção do ECI no direito constitucional brasileiro. A decisão do STF na ADPF 347 é inconsistente na caracterização dos pressupostos que justificariam a declaração de um $\mathrm{ECl}$, as medidas cautelares deferidas são pouco efetivas, há uma injustificada demora no julgamento do mérito, os poderes apresentaram respostas pouco substantivas e que seguem a mesma natureza das políticas tradicionalmente desenvolvidas no Brasil e a capacidade de uma Corte Suprema mudar um estado fático de coisas por meio do Direito é posta em dúvida.." MAGALHÃES, Breno Baía. O Estado de Coisas Inconstitucional na ADPF 347 e a sedução do Direito: o impacto da medida cautelar e a resposta dos poderes políticos. Revista Direito GV, São Paulo, v. 15, n. 2, e1916, 2019, p. 31-32. 
decidindo-a em função do crime concretamente praticado (pessoa e fatos) e não do crime abstratamente previsto em lei.

O segundo caminho refere-se à convocação ao judiciário para considerar as circunstâncias concretas de cumprimento da pena que estão prestes a impor. É o que se depreende dos pedidos c e $f$, que demandam a consideração do "quadro dramático do sistema prisional na concessão de cautelares, na aplicação e na execução da pena" e a redução do "tempo de prisão a ser cumprido, quando as condições de cumprimento são significativamente mais severas do que as impostas na sentença". Trata-se aqui de convocar o judiciário a se comprometer com a decisão que está tomando. Uma decisão que não se limita a meramente chancelar a escolha do legislador ao definir a pena prevista em lei. E, sobretudo, a se comprometer com uma decisão que não se completa no texto da sentença mas que gera uma série de efeitos no mundo, para a pessoa condenada, para seu entorno familiar e para a sociedade como um todo.

Como se viu, esses pedidos foram negados, por diversos motivos. Além de considerações sobre os limites do pedido cautelar, destaca-se nos votos considerações sobre os limites impostos pela lei. Interessante notar que os pedidos c e $f$, de certa forma semelhantes, tiveram placares muito diferentes. Quando se trata de "levar em consideração o quadro dramático" (pedido c), o placar foi 6 a 4 (vencidos os Ministros Marco Aurélio, Luiz Fux, Lewandowsi e a Ministra Carmen Lucia). Mas quando essa consideração aparece associada à redução do tempo de prisão a ser cumprido (pedido f), o pedido foi negado por unanimidade. Nesse pedido, e no pedido e, sobre o abrandamento dos requisitos temporais para fruição de "benefícios", a concessão do pedido implicaria interpretar as penas mínimas estabelecidas em lei (tanto nos tipos penais quanto nos chamados "benefícios") à luz das normas constitucionais que estabelecem a individualização da pena e que proíbem as penas cruéis. ${ }^{52}$

Ainda que negados esses pedidos em caráter liminar, as considerações sobre o "quadro dramático do sistema prisional" e as condições concretas de cumprimento das penas voltaram a aparecer na argumentação do tribunal.

No HC 118.533/MS, que afasta a natureza hedionda do tráfico privilegiado, essas considerações aparecem no voto do Ministro Barroso e depois ocupam o centro dos debates, estimulando os Ministros Fachin e Teori, bem como a Ministra Rosa Weber a reajustarem seus votos pela concessão do $\mathrm{HC}^{53}$. O voto do Ministro Barroso menciona

52 Sobre a questão da individualização da pena, ver a discussão sobre os efeitos das penas mínimas no processo sancionatório no Brasil e no Canadá, bem como sobre a decisão do STF no RE 597.270/RS que confirma a Súmula 231 do STJ que impede a redução aquém do mínimo quando se reconhece a incidência de circunstâncias atenuantes em MACHADO, Maíra Rocha. Entre a lei e o juiz: Os processos decisórios na definição de penas. Revista Brasileira de Ciências Criminais, São Paulo, n. 126, p. 181-222, 2016.

53 BRASIL. Supremo Tribunal Federal. Habeas Corpus n. 118.533/MS. Pacientes: Ricardo Evangelista Vieira de Souza; Robinson Roberto Ortega. Relator(a): Min. Carmen Lúcia. Brasília, 19 de setembro de 2016. Disponível em: http://portal.stf.jus.br/processos/detalhe.asp?incidente=4432320 (acesso em 26 de março de 
a tendência do STF em atenuar o rigor dos crimes hediondos em caso de tráfico privilegiado, permitindo o regime diferente do fechado, a pena restritiva de direito e a liberdade condicional. E aduz que essa tendência está associada ao "fracasso da guerra às drogas" e à "situação do hiperencarceramento que aflige a todos nós que vivemos no Brasil [...]"54. No mesmo sentido, o Ministro Fachin afirma que o tema tem "impacto inegavelmente imenso sobre o sistema carcerário" e que, portanto, "transcende este julgamento específico deste $\mathrm{HC}^{\prime \prime 5}$. Nos debates, Lewandowski cita dados do Infopen e afirma "a situação é dramática. É uma questão de política criminal. Eu acho que, aqui, além da questão propriamente de interpretação, de hermenêutica jurídica, há um fato que o Supremo deve considerar que é esse" ${ }^{156}$. E, mais a frente, evoca o "estado de coisas inconstitucional" e o princípio da individualização da pena para motivar sua decisão ${ }^{57}$.

Mais recentemente, considerações sobre as condições de vida em prisão e o estado de coisas inconstitucional desempenharam papel relevante no julgamento do HC Coletivo 143.641/SP. ${ }^{58}$ Em 20 de fevereiro de 2018, o STF concedeu, por maioria ${ }^{59}$, ordem em favor de "todas as mulheres submetidas à prisão cautelar no sistema penitenciário nacional, que ostentam a condição de gestantes, puérperas ou de mães com crianças com até 12 anos de idade sob sua responsabilidade, e das próprias crianças" determinando que a prisão preventiva seja substituída por prisão domiciliar. ${ }^{60} \mathrm{O}$ voto

2018). Ordem concedida conforme voto da relatora Carmen Lucia, acompanhada de Barroso, Gilmar Mendes e Lewandowski. Vencidos Fux, Toffoli e Marco Aurélio. Reajustaram, Fachin, Teori e Rosa Weber.

54 BRASIL. Supremo Tribunal Federal. Habeas Corpus n. ${ }^{\circ} 118.533 / M S$. Pacientes: Ricardo Evangelista Vieira de Souza; Robinson Roberto Ortega. Relator(a): Min. Carmen Lúcia. Brasília, 19 de setembro de 2016, p. 21-22.

55 BRASIL. Supremo Tribunal Federal. Habeas Corpus n. ${ }^{\circ} 118.533 /$ MS. Pacientes: Ricardo Evangelista Vieira de Souza; Robinson Roberto Ortega. Relator(a): Min. Carmen Lúcia. Brasília, 19 de setembro de 2016, p. 61

56 BRASIL. Supremo Tribunal Federal. Habeas Corpus n. ${ }^{\circ} 118.533 / M S$. Pacientes: Ricardo Evangelista Vieira de Souza; Robinson Roberto Ortega. Relator(a): Min. Carmen Lúcia. Brasília, 19 de setembro de 2016, p. 60

57 BRASIL. Supremo Tribunal Federal. Habeas Corpus n. ${ }^{\circ}$ 118.533/MS. Pacientes: Ricardo Evangelista Vieira de Souza; Robinson Roberto Ortega. Relator(a): Min. Carmen Lúcia. Brasília, 19 de setembro de 2016, p. 91 e 93.

58 BRASIL. Supremo Tribunal Federal. Voto do relator no Habeas Corpus n. ${ }^{143.641 / S P}$. Pacientes: Todas as mulheres submetidas à prisão cautelar no sistema penitenciário nacional, que ostentem a condição de gestantes, de puérperas ou de mães com crianças com até 12 anos de idade sob sua responsabilidade, e das próprias crianças. Relator: Ministro Ricardo Lewandowski. Disponível em <http://www.stf.jus.br/portal/cms/verNoticiaDetalhe.asp?idConteudo=370152> Acesso em 27 de março de 2018.

59 A maioria foi formada por Lewandowski, Gilmar Mendes, Dias Toffoli e Celso de Mello, com divergência somente de Fachin, para quem análises concretas e individualizadas seriam necessárias para a verificação da medida a ser tomada em prol da criança. http://www.stf.jus.br/portal/cms/verNoticiaDetalhe.asp?idConteudo=370152. Acesso em 29 de março de 2018.

60 "Em face de todo o exposto, concedo a ordem para determinar a substituição da prisão preventiva pela domiciliar - sem prejuízo da aplicação concomitante das medidas alternativas previstas no art. 319 do CPP - de todas as mulheres presas, gestantes, puérperas ou mães de crianças e deficientes, nos termos do art. $2^{\circ}$ do ECA e da Convenção sobre Direitos das Pessoas com Deficiências (Decreto Legislativo 186/2008 e Lei 13.146/2015), relacionadas neste processo pelo DEPEN e outras autoridades estaduais, enquanto perdurar tal condição, excetuados os casos de crimes praticados por elas mediante violência ou grave ameaça, contra seus descendentes ou, ainda, em situações excepcionalíssimas, as quais deverão ser devidamente fundamentadas pelo juízes que denegarem o benefício. Estendo a ordem, de ofício, às demais as mulheres presas, gestantes, puérperas ou 
do relator, Ministro Lewandowski, único disponibilizado pelo STF até a conclusão desse texto, refere-se diversas vezes ao julgamento da ADPF 347 para embasar a inadequação do sistema carcerário para as pacientes.

O HC Coletivo, impetrado por Eloísa Machado de Almeida, Bruna Soares Angotti, André Ferreira, Nathalie Fragoso, Hilem Oliveira, advogadas do Coletivo de Advogados de Direitos Humanos (CADHu), alicerça-se (i) nas privações que a prisão preventiva impõe às mulheres - programas de pré-natal e atendimento a recém nascidos e lactentes, além de privar as crianças até 12 anos de condições adequadas ao seu desenvolvimento; (ii) na precariedade das condições de vida em prisão, especialmente inadequadas às necessidades femininas e aos exercícios dos direitos reprodutivos - o que constitui tratamento desumano, cruel e degradante, nos termos do art. 5०, III, da Constituição Federal e faz com que a prisão provisória extrapole os limites constitucionais da intervenção do poder punitivo sobre o indivíduo; e, ainda, (iii) na existência de uma política criminal discriminatória, nos termos do art. $5^{\circ}, \mathrm{XLI}$, da Constituição, pelo desproporcional impacto sobre as mulheres e suas famílias ${ }^{61}$.

Foge absolutamente aos propósitos desse texto realizar um balanço sobre o sentido e a direção da jurisprudência do STF no campo criminal ${ }^{62}$. Como indicado na introdução, esse texto preocupa-se em identificar fissuras no modelo cristalizado de separação de poderes em matéria de penas. De acordo com a leitura proposta aqui, os pedidos da ADPF 347 e as decisões do HC 118.533/MS e agora do HC coletivo 143.641/ SP, de diferentes maneiras, rompem com a lógica de atribuição de responsabilidade externa e, ademais, convocam o poder judiciário a incorporar aos seus processos decisórios as peculiaridades e características das pessoas e das circunstâncias concretas de

mães de crianças e de pessoas com deficiência, bem assim às adolescentes sujeitas a medidas socioeducativas em idêntica situação no território nacional, observadas as restrições previstas no parágrafo acima." Cf. BRASIL. Supremo Tribunal Federal. Habeas Corpus n. ${ }^{\circ}$ 143.641/SP. Pacientes: Todas as mulheres submetidas à prisão cautelar no sistema penitenciário nacional, que ostentem a condição de gestantes, de puérperas ou de mães com crianças com até 12 anos de idade sob sua responsabilidade, e das próprias crianças. Relator: Ministro Ricardo Lewandowski, p. 33.

61 COLETIVO DE ADVOGADOS DE DIREITOS HUMANOS. Habeas Corpus Coletivo com pedido liminar. 8 de maio de 2017, p. 3. Disponível em < https://cadhu.wordpress.com/2018/02/27/leia-a-integra-do-habeas-corpus-coletivo-do-cadhu-peticao-inicial-documentos-amici-curiae-e-decisoes/>. Acesso em 28 de março de 2018.

62 Suficiente apontar aqui a decisão do STF no HC 126.292/RJ que estabeleceu o entendimento segundo o qual a pena poderia ser executada a partir da condenação em segunda instância. Vale lembrar que, nesse julgamento, o Ministro Lewandowski manifestou sua "perplexidade diante do fato [dessa decisão] ser tomada logo depois de nós termos assentado, na ADPF 347 e no RE 592.581, que o sistema penitenciário brasileiro está absolutamente falido. E mais, nós afirmamos, e essas são as palavras do eminente Relator naquele caso, que o sistema penitenciário brasileiro se encontra num estado de coisas inconstitucional. Então, agora, nós vamos facilitar a entrada de pessoas neste verdadeiro inferno de Dante, que é o nosso sistema prisional?". BRASIL. Supremo Tribunal Federal. Habeas Corpus n. $0^{126.292 / R J . ~ P a c i e n t e: ~ M a r c i o ~ R o d r i g u e s ~ D a n t a s . ~ R e l a t o r: ~ T e o r i ~}$ Zavascki. Brasília, 17 de maio de 2016, p. 98. Disponível em <http://www.stf.jus.br/portal/processo/verProcessoAndamento.asp? numero $=126292 \&$ classe $=H C \&$ codigoClasse $=0 \&$ origem $=J U R \&$ recurso $=0$ \&tipo Julgamento $=\mathrm{M}>$ Acesso em 27 de março de 2018. 
cumprimento de pena em nosso país. Como se viu no decorrer desta seção, em diferentes contextos, o problema carcerário não é percebido como um problema "puramente do executivo", ainda que a lei infraconstitucional seja percebida como obstáculo importante para a plena apropriação das tarefas decisórias em matéria de penas. ${ }^{63}$

De fissuras no STF, contudo, não podemos inferir fissuras semelhantes nas instâncias inferiores. Ao contrário. Em documento produzido pelo IDDD em 2017, a "edição de súmulas vinculantes que pacifiquem os entendimentos consolidados pelo STF" e a "criação de mecanismos urgentes que garantam o cumprimento das súmulas do STJ" aparecem entre as propostas para reduzir a "superlotação prisional e melhorar o sistema penitenciário". De acordo com o Instituto, "obrigar os tribunais a cumprirem a jurisprudência do STJ e do STF é um passo fundamental para democratizar o acesso à justiça e aliviar a superlotação das prisões" ${ }^{64}$. No mesmo sentido, pesquisa sobre a argumentação utilizada pelo TJSP antes e depois da declaração de inconstitucionalidade da norma que proibia penas alternativas para tráfico privilegiado revelou que o tribunal encontrou novas vias para seguir negando a substituição da pena de prisão nesses $\operatorname{casos}^{65}$.

Para avançar sobre esse ponto, a próxima seção debruça-se sobre o modo como o problema carcerário vem sendo compreendido e recepcionado no TJSP. Focaliza a atuação do tribunal em ações civis públicas e em pedidos de suspensão de decisões de primeira instância direcionados à Presidência do Tribunal, a partir dos resultados obtidos nas pesquisas de Carolina Ferreira e outras (2015) e Luciana Zaffalon Cardoso (2017). Em seguida, com vistas a identificar se, e de que modo, as decisões do STF estão reverberando no Tribunal de Justiça de São Paulo, a parte final da próxima seção revisita esses dois conjuntos de decisões após o julgamento da ADPF 347 e do RE 592.581.

\section{A REPERCUSSÃO NO TJSP}

Muito antes da declaração do estado de coisas inconstitucional, diversos atores já provocavam o poder judiciário a assumir sua responsabilidade sobre o problema

\footnotetext{
63 Nesse sentido, conforme Dantas "[e]mbora essas decisões sejam consideradas ativistas, é importante destacar que elas normalmente não envolvem grandes questionamentos acerca da existência ou conteúdo dos direitos fundamentais em disputa. Na maioria dos casos, a grande questão jurídica é saber como concretizar direitos em face da reiterada inércia e omissão estatal.." Cf. DANTAS, Eduardo Sousa. Ações estruturais, direitos fundamentais e o estado de coisas inconstitucional. Revista Constituição e Garantia de Direitos, Natal, v. 9, n. 2, p. 155-176, 2016, p. 173.

64 INSTITUTO DE DEFESA DO DIREITO DE DEFESA. Propostas para reduzir a superlotação e melhorar o sistema penitenciário. 2017, p. 15. Disponível em < http://www.iddd.org.br/index.php/2017/02/02/propostas-para-reduzir-a-superlotacao-e-melhorar-o-sistema-penitenciario/> Acesso em 27 de março de 2018.

65 MACHADO, Maíra Rocha; BARROS, Matheus de; GUARANHA, Olívia Landi Corrales; PASSOS, Julia Adib. Penas alternativas para pequenos traficantes: os argumentos do TJSP na engrenagem do superencareramento. Revista Brasileira de Políticas Públicas, Brasília, v. 8, n. 1, p. 604-629, abr. 2018.
} 
carcerário por intermédio de ações civis públicas ${ }^{66}$. Nessas ações o "problema carcerário" assume diversos contornos e se concretiza em diferentes tipos de pedido: transferência de presos, vedação de envio de novos presos a unidades superlotadas, interdição de unidades, reformas estruturais, fornecimento de recursos básicos (como colchões, água potável) e serviços de saúde, oferta de ensino fundamental e médio, além de realização de estudos de impacto ambiental e de vizinhança antes da construção de novas unidades. Inúmeros aspectos dessas ações revelam-se de enorme interesse para uma pesquisa sobre o papel do poder judiciário no enfrentamento do problema carcerário. Essa seção, contudo, limita-se a traçar um panorama do modo como esses casos vêm sendo decididos pelo TJSP, particularmente no tocante ao modelo cristalizado de separação de poderes e às fissuras geradas pela ADPF 347 e pelo RE 592.581 julgadas pelo STF em 2015.

Pesquisa realizada por Carolina Ferreira e outras em decisões do TJSP, entre 2009 e 2012, permite observar diversas estratégias argumentativas de isenção de responsabilidade interna e atribuição de responsabilidade externa (ao executivo). O conjunto de decisões analisadas versa predominante sobre obrigações de fazer: respeito ao limite de vagas do estabelecimento prisional (em casos de presos provisórios, condenados e de internação de adolescentes), interdição do estabelecimento, realização de reformas e exigência de laudos ambientais para a construção de novos estabelecimentos. Entre as obrigações de não fazer, a pesquisa identificou pedido de não alojar pessoas acima da capacidade do local, sob pena de multa diária. ${ }^{67}$

No conjunto de decisões de mérito analisadas, a pesquisa identificou que o TJSP tende a reverter as decisões procedentes tomadas em primeira instância. De acordo com a pesquisa, "(e)nquanto o juiz de primeiro grau decide pela procedência total ou parcial em 39 casos contra 11 pela improcedência, noTJSP a relação se inverte, havendo 22 casos de procedência total ou parcial contra 26 de improcedência". ${ }^{6}$

A análise qualitativa indica que os principais argumentos mobilizados pelo TJSP nessas decisões referem-se à incompetência do juízo cível para tratar de questões relacionadas a presídios e à afronta ao princípio da separação de poderes. As duas linhas

\footnotetext{
66 A primeira apelação em ação civil pública julgada pelo TJSP versando sobre o problema carcerário disponível no site do tribunal data de 21/11/2007.

67 Para um panorama completo dos dados quantitativos e qualitativos produzidos pelas pesquisadoras, ver FERREIRA, Carolina Cutrupi; FERREIRA, Luisa Moraes Abreu; VILARDI, Naiara; MACHADO, Maíra Rocha. O problema prisional nas ações civis públicas julgadas pelo TJSP. In MACHADO, Maíra Rocha; MACHADO, Marta Rodriguez de Assis (coords.). Carandiru não é coisa do passado. São Paulo: FGV Direito SP, 2015, p. $439-467$. Disponível em <http://bibliotecadigital.fgv.br/dspace/handle/10438/13989> Acesso em 28 em de março de 2018.

68 FERREIRA, Carolina Cutrupi; FERREIRA, Luisa Moraes Abreu; VILARDI, Naiara; MACHADO, Maíra Rocha. O problema prisional nas ações civis públicas julgadas pelo TJSP. In MACHADO, Maíra Rocha; MACHADO, Marta Rodriguez de Assis (coords.). Carandiru não é coisa do passado. São Paulo: FGV Direito SP, 2015, p. 451. Disponível em <http://bibliotecadigital.fgv.br/dspace/handle/10438/13989> Acesso em 28 em de março de 2018.
} 
argumentativas são reveladoras do que denominamos aqui modelo cristalizado de separação de poderes. Na raiz da primeira linha está a compreensão de que transferências de presos e interdições são questões "de natureza administrativa" e de competência do juiz de execução e da corregedoria de presídios. Em um dos acórdãos citados na pesquisa, o argumento aparece nos seguintes termos: "Há dúvida quanto a poder um juiz interferir dessa forma na esfera de atuação de outro; ainda que em atribuição administrativa, os presídios são fiscalizados por um juiz de direito a quem a lei atribuiu a adequação dos presídios à lei. (...) Causa desconforto a interferência do juízo no dia a dia do presídio, este de responsabilidade do Diretor do Presídio sob fiscalização do Juiz Corregedor Permanente. (grifos meus)"69. Essa passagem nos ajuda a visualizar a dimensão que pode tomar o modelo cristalizado: entre diferentes órgãos, no interior do próprio poder judiciário, pode-se funcionar por isenção de responsabilidade. Se há provas dos fatos sobre os quais versa a ação civil pública, significa que os órgãos diretamente competentes não cumpriram suas obrigações legais. Com este tipo de argumento, evita-se adentrar a questão substantiva em jogo, em razão dos "desconfortos" que tal atuação pode gerar.

No tocante à segunda linha argumentativa, a pesquisa identificou duas correntes. A primeira considera que o Judiciário não pode interferir em decisão governamental, com base em interpretação do art. $2^{\circ}$ da CF segundo a qual compete ao Executivo "a função de executar as leis, fica(ndo) claro que ao Poder Judiciário não compete dizer quanto e como executar suas funções"70. A pesquisa apresenta diversas decisões que ilustram o argumento segundo o qual "a superlotação carcerária é uma questão pertinente apenas ao Poder Executivo e, por consequência, todas as medidas relacionadas ao problema, como a transferência de presos, promoção de reformas e desativação de unidades também estariam no âmbito da discricionariedade administrativa".71

Já a segunda corrente admite a atuação do Judiciário nesses casos, desde que seja para garantir a legalidade dos atos administrativos. Em alguns casos, esta argumentação aparece associada ao princípio da dignidade da pessoa humana e outras convenções internacionais de proteção de direitos humanos. É o que se observa, por exemplo, em trecho de acórdão citado na pesquisa que afirma: "respeito, dignidade

\footnotetext{
69 TJSP, Apelação Cível 0000787-16.2008.8.26.0142, 2ª Câmara de Direito Público, Rel. Des. Lineu Peinado, j. 08.02.2011.

70 TJSP, Agravo de Instrumento 187686-24.2012.8.26.0000, 11 a Câmara de Direito Público, Rel. Des. Rubens Rihl, j. 19.09.2012.

71 FERREIRA, Carolina Cutrupi; FERREIRA, Luisa Moraes Abreu; VILARDI, Naiara; MACHADO, Maíra Rocha. O problema prisional nas ações civis públicas julgadas pelo TJSP. In MACHADO, Maíra Rocha; MACHADO, Marta Rodriguez de Assis (coords.). Carandiru não é coisa do passado. São Paulo: FGV Direito SP, 2015, p. 456. Disponível em <http://bibliotecadigital.fgv.br/dspace/handle/10438/13989> Acesso em 28 em de março de 2018.
} 
humana e condições de ressocialização aos presos são obrigações do Estado e dever do Judiciário exigir a efetivação desses Direitos"72.

Esses posicionamentos são minoritários, prevalecendo argumentos que afastam a responsabilidade do Poder Judiciário no enfrentamento do problema. A pesquisa conclui indicando que, no TJSP, as ações civis públicas, especialmente no tocante à transferência de presos e à interdição de estabelecimentos "encontra grandes resistências em se efetivar como estratégia de minimização ou alteração do problema prisional". ${ }^{73}$

Outra pesquisa, concluída recentemente, acrescenta novos elementos a esse quadro de resistências às estratégias jurisdicionais de alteração do problema prisional.

Em tese de doutorado sobre o sistema de justiça paulista, Luciana Zaffalon Cardoso apresenta os resultados de um levantamento sobre as decisões tomadas pela Presidência do TJSP para suspender os efeitos de decisões judiciais de primeira instância tomadas contra a administração pública ${ }^{74}$. Essa competência está prevista em diversos diplomas normativos e vem sendo debatida pelos tribunais superiores e pela doutrina ${ }^{75}$.

Em sua tese, Luciana Cardoso analisou 487 decisões referentes a pedidos de suspensão nas gestões de Ivan Sartori (2012 - 2013) e Renato Nalini (2014 - 2015). De acordo com os resultados da pesquisa, os temas em que há acolhimento dos pedidos de suspensão são sensivelmente concentrados, e os pedidos relacionados ao problema carcerário estão entre eles. No período coberto pela pesquisa, chegaram ao tribunal

72 TJSP, Embargos Infringentes 9092747-45.2002.8.26.0000/50000, 3a Câmara de Direito Público, Rel. Des. Antonio Carlos Malheiros, j. 06.12.2011.

73 FERREIRA, Carolina Cutrupi; FERREIRA, Luisa Moraes Abreu; VILARDI, Naiara; MACHADO, Maíra Rocha. O problema prisional nas ações civis públicas julgadas pelo TJSP. In MACHADO, Maíra Rocha; MACHADO, Marta Rodriguez de Assis (coords.). Carandiru não é coisa do passado. São Paulo: FGV Direito SP, 2015, p. 466. Disponível em <http://bibliotecadigital.fgv.br/dspace/handle/10438/13989> Acesso em 28 em de março de 2018.

74 CARDOSO, Luciana Zaffalon Leme. Uma espiral elitista de afirmação corporativa: blindagens e criminalizações a partir do imbricamento das disputas do sistema de justiça paulista com as disputas da política convencional. 336 p. Tese (doutorado) - Escola de Administração de Empresas de São Paulo, 2017. Disponível em: $<$ https://bibliotecadigital.fgv.br/dspace/handle/10438/2204/browse?value=Cardoso\%2C+Luciana+Zaffalon+Leme\&type=author $>$ Acesso em 23 mar. 2018.

75 Ver, em especial Lei 8437/92, e também Lei 7347/85, art. 12, § 1º, Lei 8437/92, art. 4º, §§ $1^{\circ}$ ao $9{ }^{\circ}$, Lei 9407/97, art. 16, Lei 12016/09, art. 15, §§ $1^{\circ}$ ao $5^{\circ}$. A medida de suspensão de segurança é considerada um instrumento de proteção do interesse público diante da concessão de um provimento jurisdicional que cause grave lesão à ordem, à saúde, à segurança e à economia públicas, por meio do qual a pessoa jurídica de direito público interessada ou o Ministério Público requerem ao presidente do Tribunal competente a suspensão da execução da decisão, sentença ou acordão proferido. Não tem natureza recursal, mas a finalidade de cessar os efeitos de uma liminar ou sentença até o trânsito em julgado. Sobre sua natureza (jurídica ou política), legitimidade e competência de julgamento, ver, entre outros, STF, RE 798740 AgR, rel. p/ acórdão min. Marco Aurélio, $1^{a}$ Turma, j. 01/09/2015; STF, AgRgSS 432-DF, DJU 12.2.1993, Min. Sepúlveda Pertence; Súmula 626 do STF. E, ainda, VENTURI, Elton. Suspensão de liminares e sentenças contrárias ao Poder Público. 2.ed. São Paulo: Ed. RT, 2010. 
15 pedidos nessa temática e em 13 deles a decisão de primeira instância foi suspensa atendendo aos pedidos do Governo do Estado de São Paulo.

Nove dos 15 casos referem-se diretamente ao quadro de superlotação e condições de vida insalubres em Centros de Detenção Provisória, Penitenciárias e unidades da Fundação $\mathrm{Casa}^{76}$. De acordo com a pesquisa, a Presidência do TJSP suspendeu as decisões de primeira instância favoráveis aos pedidos com fundamentação concisa - de 5 a 8 páginas - que seguem "rigorosos padrões de repetição.".77 Basicamente, argumentam que a decisão de primeira instância exige aportes financeiros que "implica embaraço ao adequado exercício das funções da Administração", que representa violação à ordem pública provimento judicial que obstaculiza ou dificulta, sem causa legítima, o adequado exercício das funções da Administração e que o "déficit de vagas (...) é um problema antigo e alcança todo o Estado de São Paulo (...) o que sugere análises e ponderações de todo o sistema" e não de unidades isoladas. O quarto argumento sistematicamente utilizado nessas decisões refere-se ao alinhamento "com a jurisprudência do Pretório Excelso", especificamente a decisão da Ministra Ellen Gracie, nos seguintes termos: "no caso em tela, encontra-se presente a possibilidade de grave lesão à segurança pública, uma vez que a decisão, cujos efeitos se pretendem suspender, impede o encaminhamento de novos presos ao estabelecimento penal, circunstância que poderá colocar em risco a integridade física e patrimonial dos cidadãos, bem como que a transferência dos detentos, exigirá um dispêndio financeiro imediato por parte do Estado, que, por certo, não tem previsão orçamentária, o que comprometeria a execução do orçamento estadual (SL 93, Relator(a): Min. PRESIDENTE, Decisão Proferida pelo(a) Ministro(a) ELLEN GRACIE, julgado em 08/05/2006)." (grifos meus) ${ }^{78}$.

Além dessa decisão - em que a Ministra opõe, como na epígrafe desse texto, "detentos" e os "cidadãos", afirmando que às custas da integridade física e moral dos primeiros busca-se não colocar em risco a integridade física e patrimonial dos últimos - outro precedente do STF aparece reiteradamente nas decisões do TJSP analisadas acima. Trata-se do Recurso Extraordinário 422.298/2006, de relatoria do Ministro Eros Grau, que registra textualmente: “a forma como o Estado-membro vai garantir o direito

76 Os outros casos tratam de direito à saúde da população prisional, interdição temporária de unidade prisional e realização de estudos de impacto ambiental para a instalação de novos presídios.

77 CARDOSO, Luciana Zaffalon Leme. Uma espiral elitista de afirmação corporativa: blindagens e criminalizações a partir do imbricamento das disputas do sistema de justiça paulista com as disputas da política convencional. 336 p. Tese (doutorado) - Escola de Administração de Empresas de São Paulo, 2017. p. 224. Disponível em: $<$ https://bibliotecadigital.fgv.br/dspace/handle/10438/2204/browse?value=Cardoso\%2C+Luciana+Zaffalon+Leme\&type=author $>$ Acesso em 23 mar. 2018.

78 Todas as citações desse parágrafo foram extraídas de CARDOSO, Luciana Zaffalon Leme. Uma espiral elitista de afirmação corporativa: blindagens e criminalizações a partir do imbricamento das disputas do sistema de justiça paulista com as disputas da política convencional. 336 p. Tese (doutorado) - Escola de Administração de Empresas de São Paulo, 2017. p. 225-226. Disponível em: <https://bibliotecadigital.fgv.br/dspace/handle/10438/2204/browse?value=Cardoso\%2C+Luciana+Zaffalon+Leme\&type=author $>$ Acesso em 23 mar. 2018. 
à segurança pública há de ser definida no quadro de políticas sociais e econômicas cuja formulação é atribuição exclusiva do Poder Executivo. Não cabe ao Judiciário determinar a realização de obras em cadeia pública"79.

No entanto, em 12 de agosto de 2015, no Recurso Extraordinário 592.581 relatado pelo Min. Lewandowski, em que houve reconhecimento de repercussão geral, o STF firma nova posição, nos seguintes termos: “É lícito ao Judiciário impor à Administração Pública obrigação de fazer, consistente na promoção de medidas ou na execução de obras emergenciais em estabelecimentos prisionais para dar efetividade ao postulado da dignidade da pessoa humana e assegurar aos detentos o respeito à sua integridade física e moral, nos termos do que preceitua o art. $5^{\circ}, \mathrm{XLIX}$, da Constituição Federal, não sendo oponível à decisão o argumento da reserva do possível nem o princípio da separação dos poderes" (RE 592.581, p. 56).

De maneira explícita, o STF submete o argumento da separação de poderes, na formulação cristalizada que discutimos aqui, ao respeito à integridade física e moral das pessoas em privação de liberdade ${ }^{80}$. Diante dessa guinada jurisprudencial, realizamos novo levantamento nas decisões da Presidência do TJSP e nos acórdãos do mesmo tribunal no âmbito de ações civis públicas, com vistas a identificar se, e de que modo, o RE 592.581 repercutiu nas decisões do Tribunal sobre o problema carcerário.

No tocante à Presidência do Tribunal, a busca no biênio 2016-2017 resultou em 223 decisões, das quais 4 referem-se ao problema carcerário. Nas quatro as decisões de primeira instância foram suspensas. Três delas impediam o ingresso de novos presos em unidades e a quarta sobrestava a construção de unidade prisional em razão da ausência de estudo de impacto ambiental e de vizinhança, bem como de licenças de instalação e operação. ${ }^{81} \mathrm{~A}$ fundamentação das 3 primeiras decisões é idêntica, apoia-se no argumento do "problema antigo" que alcança "a quase totalidade dos estabelecimentos do Estado" e que portanto não pode ser solucionado "isoladamente", na ausência de previsão orçamentária e no precedente da Ministra Ellen Gracie de 2006, citado acima.

79 BRASIL. Supremo Tribunal Federal. Recurso Extraordinário 422.298/PR. Recorrente: Ministério Público do Estado do Paraná. Recorrido: Estado do Paraná. Relator: Ministro Eros Grau. Brasília, 07 de agosto de 2006.

80 Sobre essa decisão ver STEINMETZ, Wilson; DE MARCO, Cristhian Magnus. A integridade física e moral dos presos: a intervenção do poder judiciário na política carcerária e a decisão do Supremo Tribunal Federal no recurso extraordinário n. 592.581. EJJL-Espaço Jurídico: Journal of Law, v. 16, n. 2, p. 655-666, 2015.

81 BRASIL.Tribunal de Justiça de São Paulo. Decisão monocrática em processo n 2189616-04.2016.8.26.0000. Requerente: Estado de São Paulo. Requerido: MM Juiz de Direito da $1^{a}$ Vara Cível de Andradina. Paulo Dimas Mascaretti. São Paulo, 19 set. 2019; BRASIL. Tribunal de Justiça de São Paulo. Decisão monocrática em processo n 2233862-51.2017.8.26.0000. Requerente: Fazenda Pública do Estado de São Paulo. Requerida: MMa. Juíza de Direito da $1^{\circ}$ Vara da Comarca de Garça. Paulo Dimas Mascaretti. São Paulo, 22 jan. 2018; BRASIL. Tribunal de Justiça de São Paulo. Decisão monocrática em processo n 2127551-36.2017.8.26.0000 Requerente: Fazenda Pública do Estado de São Paulo. Requerido: MM. Juiz de Direito da Vara da Fazenda Pública da Comarca de São Vicente. Paulo Dimas Mascaretti. São Paulo, 24 jul. 2017. BRASIL. Tribunal de Justiça de São Paulo. Decisão monocrática em processo n 2085454-21.2017.8.26.0000. Requerente: Fazenda Pública do Estado de São Paulo. Requeridos: MM. Juízes de Direito da Vara da Fazenda Pública da Comarca de São Vicente

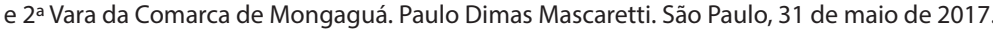


As quatro decisões não mencionam o RE 592.581/2015, mas também não mobilizam diretamente os argumentos relacionados à separação de poderes cristalizada, explicitamente afastados naquela decisão.

Já o levantamento realizado seguindo os critérios de coleta de acórdãos utilizado na pesquisa de Carolina Ferreira e outras, indicado acima, revela que tanto o RE 592.581 quanto a própria ADPF 347 começaram a reverberar nas decisões do Tribunal. Entre as 26 decisões em ações civis públicas julgadas nos anos de 2016 e 2017 sobre o problema carcerário e disponibilizadas no site do tribunal, 11 (onze) mencionam explicitamente o RE e/ou a ADPF. Mais especificamente, 9 (nove) decisões mencionam ambas, uma menciona apenas o RE e uma menciona só a ADPF.

Entre essas 26 decisões, cinco se referem a questões ambientais e uma ao tema das faltas disciplinares e não serão consideradas no levantamento a seguir. Das 20 restantes, 14 decisões consideraram procedentes total ou parcialmente os pedidos realizados pelos autores da ação: adequação da população carcerária aos limites físicos do presídio, seja através de redução do número de presos ou de não admissão de novos reclusos; garantia de acesso à saúde, através da implementação ou manutenção de equipes médicas nos estabelecimentos prisionais; garantia de acesso à educação, através do oferecimento de ensino fundamental e médio em um presídio feminino; realização de reformas nos edifícios em questão; e, por meio do provimento de uma liminar de tutela de urgência, a oferta de água potável e colchão aos presos.

Dentre essas 14 decisões favoráveis, há quatro que não mencionam a ADPF ou RE e se baseiam em outros argumentos, como a observância de normas constitucionais já existentes e de normativas internacionais, conjugadas com a grave violação de direitos fundamentais - como a dignidade da pessoa humana. E indicam que não se trata de "ingerência indevida" mas de "cumprimento do dever constitucional"82. Merece destaque uma decisão que anula a sentença de primeira instância - que havia julgado improcedente o pedido do Ministério Público de não admitir novos detentos em unidade superlotada e realizar obras emergenciais - e determina nova instrução probatória. Nessa decisão, o relator indica que está de acordo com a posição do juiz de primeiro grau, segundo a qual "não poderia o Judiciário imiscuir-se nos assuntos relacionados

\footnotetext{
82 Nesse sentido, discorre o Des. Antonio Cortez: “De fato, não mais prevalece o dogma absoluto da incensurabilidade dos atos da Administração Pública pelo Judiciário, assim como não se admite a mera sobreposição de um juízo valorativo judicial ao do administrador. (...) Reconhecer e garantir a efetividade de direitos não implica ingerência indevida do Poder Judiciário na área de atuação de outro Poder, mas efetivo cumprimento de seu próprio dever constitucional, que há de ser exercido mesmo contra o Estado... BRASIL. Tribunal de Justiça do Estado de São Paulo. Acórdão n 0029550-40.2010.8.26.0309. Relator: Des. Antonio Celso Aguilar Cortez. São Paulo, 30 set. 2016, p. 6.
} 
à política pública penitenciária". Mas, diante do RE 592.581, diz o relator: "curvo-me ao posicionamento firmado pelo C. STF (... $)^{83 \prime \prime}$

Mas há também uma decisão que menciona a ADPF e o RE e nega os pedidos formulados na ação. No acórdão em questão, destaca-se o trecho em que se reconhece que o STF "já sinalizou para o conjunto do Poder Judiciário a necessidade de observância da inafastabilidade de jurisdição nesse tipo de controvérsia" mas que, por outro lado, a decisão proferida na ADPF tem "caráter provisório" e "restrito alcance" tendo em vista que somente os pedidos sobre as audiências de custódia e FUNPEN foram concedidos $^{84}$.

Por último, vale pontuar que, das nove decisões que não mencionam nem o RE nem a ADPF, cinco determinam ou mantém a decisão desfavorável aos autores da ação. São de três pedidos de remoção de presos para outros estabelecimentos prisionais, por conta de superlotação e más condições dos estabelecimentos (um deles também requer a interdição da cadeia pública em questão); um pedido sobre assistência de saúde; e um de construção de nova unidade de internação da Fundação Casa.

\section{CONSIDERAÇÕES FINAIS}

A epígrafe deste texto parece reconhecer a existência do problema carcerário mas vincula-o "puramente" ao poder executivo, isto é, à ampliação do sistema prisional por intermédio da construção de novas vagas. A experiência colombiana escancara o fracasso desse tipo de estratégia.

Este texto procurou mostrar que essa forma de compreender o problema carcerário subtrai o papel central que o poder judiciário pode e deve desempenhar tanto no curto prazo - modificando diretamente a situação das pessoas em privação de liberdade, como no caso do recém julgado HC coletivo - quanto no médio e longo prazo - por intermédio das medidas de desencarceramento elencadas pelos autores da ADPF 347. Ainda que negados cautelarmente esses pedidos, foi possível observar que a declaração do estado de coisas inconstitucional está reverberando em outras decisões do STF e também do TJSP.

Abre-se aqui uma ampla agenda de pesquisas sobre a extensão e o alcance das fissuras que o STF está provocando no modelo cristalizado de separação de poderes em matéria de penas. Ao lado do monitoramento da repercussão dessas decisões em outros tribunais e nos anos que estão por vir, é imprescindível repertoriar também se,

83 BRASIL.Tribunal de Justiça do Estado de São Paulo. Acórdão em Apelação n 0004883-94.2014.8.26.0326. São Paulo, 19 mai. 2016.

84 BRASIL. Tribunal de Justiça do Estado de São Paulo. Decisão em Agravo de Instrumento n 206884475.2017.8.26.0000. Relator: Des. Luciana Bresciani. São Paulo, 24 ago. 2017. 
e de que modo, estão reverberando nas decisões tomadas cotidianamente nas audiências de custódia, nas sentenças condenatórias e no decorrer do processo de execução.

Do levantamento realizado neste texto não é possível inferir que as decisões de 2015 do STF - ADPF 347 e RE 592.581 - tenham se tornado um divisor de águas no modo como o TJSP decide os recursos em ações civis públicas ou nos pedidos de suspensão dirigidos à Presidência do Tribunal. Mas, como se viu, estão provocando o Tribunal a levar as "dramáticas condições carcerárias" em consideração, a "se curvar" ao entendimento do STF ou, ao menos, a indicar os limites da decisão cautelar. A menção frequente a essas decisões, nos dois anos subsequentes, não pode ser negligenciada. Ao contrário, pode indicar, se lidas com otimismo, que as fissuras no modelo cristalizado de separação de poderes em matéria penal estão encontrando eco até mesmo em instâncias historicamente refratárias a assumir sua parcela de responsabilidade pelo problema carcerário.

\section{REFERÊNCIAS}

AGUIRRE, Carlos. Cárcere e sociedade na América Latina: 1800-1940. In: MAIA, Clarissa; SÁ NETO, Flávio de; COSTA, Marcos; BRETAS, Marcos Luiz (orgs.). História das prisões no Brasil: volume 1. Rio de Janeiro: Rocco, 2009, p. 35-77.

ARIZA, Libardo José. La prisión ideal: intervención judicial y reforma del sistema penitenciario en Colombia. In: BONILLA, Daniel; ITURRALDE, Manuel (eds.). Hacia un nuevo derecho constitucional. Bogotá: Ediciones Uniandes, 2005, p. 283-328.

BRASIL. Departamento Penitenciário Nacional. Levantamento Nacional de Informações Penitenciárias: Junho/2017. Brasília: Departamento Penitenciário Nacional, 2019. Disponível em: http://depen.gov.br/DEPEN/depen/sisdepen/infopen/relatorios-sinteticos/infopen-jun-2017-rev-12072019-0721.pdf Acesso: 20 abr. 2020.

BRASIL. Supremo Tribunal Federal. Acórdão. Arguição de Descumprimento de Preceito Fundamental (ADPF) no 347. Relator: Min. Marco Aurélio. Brasília, DF. Publicado em: 19 fev. 2016. Disponível em: <http://redir.stf.jus.br/paginadorpub/paginador.jsp?docTP=TP\&doclD=10300665>. Acesso em: 26 mar. 2018.

BRASIL. Supremo Tribunal Federal. Habeas Corpus n. $118.533 /$ MS. Pacientes: Ricardo Evangelista Vieira de Souza; Robinson Roberto Ortega. Relator(a): Min. Carmen Lúcia. Brasília, 19 de setembro de 2016. Disponível em: http://portal.stf.jus.br/processos/detalhe.asp?incidente $=4432320$ (acesso em 26 de março de 2018).

BRASIL. Supremo Tribunal Federal. Habeas Corpus n.0 126.292/RJ. Paciente: Marcio Rodrigues Dantas. Relator: Teori Zavascki. Brasília, 17 de maio de 2016, p. 98. Disponível em <http://www.stf. jus.br/portal/processo/verProcessoAndamento.asp?numero $=126292 \&$ classe $=$ HC\&codigoClasse=0\&origem=JUR\&recurso=0\&tipoJulgamento=M> Acesso em 27 de março de 2018. 
BRASIL. Supremo Tribunal Federal. Petição Inicial na Arguição de Descumprimento de Preceito Fundamental (ADPF) $\mathbf{n}^{\circ}$ 347. Rio de Janeiro, 26 de maio de 2015. Disponível em: <http:// www.jota.info/wp-content/uploads/2015/05/ADPF-347.pdf>. Acesso em: 26 mar. 2018.

BRASIL. Supremo Tribunal Federal. Recurso Extraordinário 422.298/PR. Recorrente: Ministério Público do Estado do Paraná. Recorrido: Estado do Paraná. Relator: Ministro Eros Grau. Brasília, 07 de agosto de 2006.

BRASIL. Supremo Tribunal Federal. Recurso Extraordinário n. 592.581/RS. Recorrente: Ministério Público do Rio Grande do Sul. Recorrido: Estado do Rio Grande do Sul. Relator: Ministro Ricardo Lewandowski. Brasília, 01 de fevereiro de 2016. Disponível em < http://portal.stf.jus.br/ processos/detalhe.asp?incidente=2637302 > . Acesso em 28 de março de 2018.

BRASIL. Supremo Tribunal Federal. Voto do relator no Habeas Corpus n. ${ }^{0} 143.641 / S P$. Pacientes: Todas as mulheres submetidas à prisão cautelar no sistema penitenciário nacional, que ostentem a condição de gestantes, de puérperas ou de mães com crianças com até 12 anos de idade sob sua responsabilidade, e das próprias crianças. Relator: Ministro Ricardo Lewandowski. Disponível em < http://www.stf.jus.br/portal/cms/verNoticiaDetalhe.asp?idConteudo=370152> Acesso em 27 de março de 2018.

BRASIL. Tribunal de Justiça de São Paulo. Decisão monocrática em processo n 2189616 04.2016.8.26.0000. Requerente: Estado de São Paulo. Requerido: MM Juiz de Direito da 1a Vara Cível de Andradina. Paulo Dimas Mascaretti. São Paulo, 19 set. 2019.

BRASIL. Tribunal de Justiça de São Paulo. Decisão monocrática em processo n 2233862 51.2017.8.26.0000. Requerente: Fazenda Pública do Estado de São Paulo. Requerida: MMa. Juíza de Direito da $1^{\circ}$ Vara da Comarca de Garça. Paulo Dimas Mascaretti. São Paulo, 22 jan. 2018.

BRASIL. Tribunal de Justiça de São Paulo. Decisão monocrática em processo n 2127551 36.2017.8.26.0000 Requerente: Fazenda Pública do Estado de São Paulo. Requerido: MM. Juiz de Direito da Vara da Fazenda Pública da Comarca de São Vicente. Paulo Dimas Mascaretti. São Paulo, 24 jul. 2017.

BRASIL. Tribunal de Justiça de São Paulo. Decisão monocrática em processo n 208545421.2017.8.26.0000. Requerente: Fazenda Pública do Estado de São Paulo. Requeridos: MM. Juízes de Direito da Vara da Fazenda Pública da Comarca de São Vicente e 2a Vara da Comarca de Mongaguá. Paulo Dimas Mascaretti. São Paulo, 31 de maio de 2017.

BRASIL. Tribunal de Justiça do Estado de São Paulo. Acórdão n 0029550-40.2010.8.26.0309. Relator: Des. Antonio Celso Aguilar Cortez. São Paulo, 30 set. 2016.

BRASIL. Tribunal de Justiça do Estado de São Paulo. Decisão em Agravo de Instrumento no 2068844-75.2017.8.26.0000. Relator: Des. Luciana Bresciani. São Paulo, 24 ago. 2017.

BUSTAMANTE PEÑA, Gabriel. Estado de cosas inconstitucional y políticas públicas. 2011. Maestría (Estudios Políticos) - Pontificia Universidad Javeriana, Bogotá, D.C., 2011. Disponível em: 
$<$ http://participaz. com/images/pdf/Capitulo6/estado_de_cosas_insconstitucional.pdf $>$. Acesso em: 01 jun. 2020.

CAMPOS, Carlos Alexandre de Azevedo. Da Inconstitucionalidade por Omissão ao Estado de Coisas Inconstitucional. 248 pp. Tese (Doutorado). Programa de Pós-graduação em Direito: Universidade Estadual do Rio de Janeiro, 2015. Disponível em: http://www.bdtd.uerj.br/tde_busca/ arquivo.php?codArquivo=8742. Acesso em: 07 jul. 2020.

CARDOSO, Luciana Zaffalon Leme. Uma espiral elitista de afirmação corporativa: blindagens e criminalizações a partir do imbricamento das disputas do sistema de justiça paulista com as disputas da política convencional. 336 p. Tese (doutorado) - Escola de Administração de Empresas de São Paulo, 2017. Disponível em: <https://bibliotecadigital.fgv.br/dspace/handle/10438/2204/ browse?value=Cardoso\%2C+Luciana+Zaffalon+Leme\&type=author $>$ Acesso em 23 mar. 2018.

CARRANZA, Elías. Cárcel y justicia penal: el modelo de derechos y obligaciones de las Naciones Unidas, y una política integral de seguridade de los habitantes frente el delito. In: CARRANZA, Elías (coord.). Criminalidad, cárcel y justicia penal en America Latina y el Caribe. México: Siglo XXI Editores, 2009, p. 53-126.

COLETIVO DE ADVOGADOS DE DIREITOS HUMANOS. Habeas Corpus Coletivo com pedido liminar. 8 de maio de 2017. Disponível em < https://cadhu.wordpress.com/2018/02/27/leia-a-integra-do-habeas-corpus-coletivo-do-cadhu-peticao-inicial-documentos-amici-curiae-e-decisoes/>. Acesso em 28 de março de 2018.

COLOMBIA. Corte Constitucional. Sentencia 559/97. Bogotá, 6 de noviembre de 1997. Disponível em < http://www.corteconstitucional.gov.co/relatoria/1997/SU559-97.htm> Acesso em 27 de março de 2018.

COLOMBIA. Corte Constitucional. Sentencia de Tutela n. 153/98. Magistrado Responsável: Eduardo Cifuentes Muñoz. Bogotá, 28 de abril de 1998. Disponível em <https://app.vlex.com/\#$\mathrm{vid} / 43561621>$ acesso em 27 de março de 2018.

CORTE INTERAMERICANA DE DIREITOS HUMANOS. Caso Tibi vs. Equador. Sentença de 7 de setembro de 2004, voto de Sergio García Ramírez, p. 17. Disponível em <http://www.corteidh.or.cr/ docs/casos/articulos/seriec_114_esp.pdf> Acesso em 27 de março de 2018.

DANTAS, Eduardo Sousa. Ações estruturais, direitos fundamentais e o estado de coisas inconstitucional. Revista Constituição e Garantia de Direitos, Natal, v. 9, n. 2, p. 155-176, 2016. Disponível em: https://periodicos.ufrn.br/constituicaoegarantiadedireitos/article/view/12258. Acesso em: 03 jul. 2020.

DE GIORGI, Raffaele; FARIA, José Eduardo; CAMPILONGO, Celso. Estado de Coisas Inconstitucional. Estadão, 19 de setembro de 2015. Disponível em: http://opiniao.estadao.com.br/noticias/geral,estado-de-coisas-inconstitucional,10000000043. Acesso em: 27 mar. 2018. 
DIMOULIS, Dimitri. Direito penal constitucional: garantismo na perspectiva do pragmatismo jurídico-político. Belo Horizonte: Arraes, 2016.

FERREIRA, Carolina Cutrupi; FERREIRA, Luisa Moraes Abreu; VILARDI, Naiara; MACHADO, Maíra Rocha. O problema prisional nas ações civis públicas julgadas pelo TJSP. In: MACHADO, Maíra Rocha; MACHADO, Marta Rodriguez de Assis (coords.). Carandiru não é coisa do passado. São Paulo: FGV Direito SP, 2015, p. 439-467. Disponível em < http://bibliotecadigital.fgv.br/dspace/ handle/10438/13989>. Acesso em 28 em de março de 2018.

GARAVITO, César Rodríguez; FRANCO, Diana. Cortes y Cambio Social: como la Corte Constitucional transformó el desplazamiento forzado en Colombia. Bogotá: Centro de Estudios de Derecho, Justicia y Sociedad, 2010. Disponível em: https:/www.dejusticia.org/wp-content/uploads/2017/04/fi_name_recurso_185.pdf. Acesso em: 03 jul. 2020.

GARAVITO, César Rodríguez. Más allá del desplazamiento, o cómo superar un estado de cosas inconstitucional. In: GARAVITO, César Rodríguez (coord.). Más allá del desplazamiento, o cómo superar un estado de cosas inconstitucional. Bogotá: Universidad de los Andes, Facultad de Derecho, Ediciones Uniandes, 2009, p. 434-493.

INSTITUTO DE DEFESA DO DIREITO DE DEFESA. Propostas para reduzir a superlotação e melhorar o sistema penitenciário. 2017. 20p. Disponível em: http://www.iddd.org.br/index. php/2017/02/02/propostas-para-reduzir-a-superlotacao-e-melhorar-o-sistema-penitenciario/. Acesso em: 27 mar. 2018.

INTER-AMERICAN COMISSION OF HUMAN RIGHTS. Report on the Human Rights of Persons Deprived of Liberty in the Americas. 2011. Disponível em: http://www.oas.org/en/iachr/pdl/docs/ pdf/ppl2011eng.pdf. Acesso em: 27 mar. 2018.

LAGE, Daniel; BRUGGER, Andrey. Estado de coisas inconstitucional: legitimidade, utilização e considerações. Revista Publicum, Rio de Janeiro, v. 3, n. 2, p. 193-240, jul./dez. 2017.

LEAL, César Barros. Execução penal na América Latina à luz dos direitos humanos: viagem pelos caminhos da dor. 1 ed. 2a reimpressão. Curitiba: Juruá, 2009.

MACHADO, Maíra Rocha. Entre a lei e o juiz: Os processos decisórios na definição de penas. Revista B rasileira de C iências C riminais, São Paulo, n. 126, p. 181-222, dez, 2016.

MACHADO, Maíra Rocha; BARROS, Matheus de; GUARANHA, Olívia Landi Corrales; PASSOS, Julia Adib. Penas alternativas para pequenos traficantes: os argumentos do TJSP na engrenagem do superencareramento. Revista Brasileira de Políticas Públicas, Brasília, v. 8, n. 1, p. 604-629, abr. 2018.

MENDES, Gilmar Ferreira; BRANCO, Paulo Gustavo Gonet. Curso de Direito Constitucional. 14 ed. São Paulo: Saraiva, 2019.

MAGALHÃES, Breno Baía. O Estado de Coisas Inconstitucional na ADPF 347 e a sedução do Direito: o impacto da medida cautelar e a resposta dos poderes políticos. Revista Direito GV, São Paulo, 
v. 15, n. 2, e1916, 2019. Disponível em: http://www.scielo.br/scielo.php?script=sci_arttext\&pid=S1808-24322019000200203\&lng=en\&nrm=iso. Acesso em: 03 jul. 2020.

PÁEZ, Nicolás Augusto Romero. La doctrina del estado de cosas inconstitucional en Colombia: novedades del neoconstitucionalismo y "la inconstitucionalidad de la realidad". Derecho Público Iberoamericano, Santiago, n. 1, p. 243-264, out. 2012. Disponível em: https://www.derechoiberoamericano.cl/wp-content/uploads/2018/04/RDPI-1.pdf. Acesso em: 03 jul. 2020.

PALMA, Juliana Bonacorsi de; MARQUES NETO, Floriano de Azevedo. Os Sete Impasses do Controle da Administração Pública no Brasil. In: Marcos Augusto Perez; Rodrigo Pagani de Souza. (Org.). Controle da Administração Pública. Belo Horizonte: Fórum, 2016, p. 21-38

RODRIGUEZ, José Rodrigo. Estado de Coisas Surreal. JOTA, 25 de setembro de 2015. Disponível em: https://www.jota.info/opiniao-e-analise/artigos/estado-de-coisas-surreal-25092015. Acesso em: 27 mar. 2018.

SANTOS, Helena; Vieira, José; DAMASCENO, Luana e CHAGAS, Tainá. Estado de coisas inconstitucional: um estudo sobre os casos colombiano e brasileiro. Quaestio luris, Rio de Janeiro, v. 8, n. 4, p. 2595-2612, 2015. Disponível em: https://www.e-publicacoes.uerj.br/index.php/quaestioiuris/article/view/20941. Acesso em: 03 jul. 2020.

SANTOS, Hugo Leonardo Rodrigues. Futuro pretérito da prisão e a razão cínica do grande encarceramento: três momentos de emergência de discursos, expectativas e experiências acumuladas em torno do conceito de prisão. Revista Brasileira de Ciências Criminais, São Paulo, v. 131, p. 145-185, maio 2017.

SINHORETTO, Jacqueline; SILVESTRE, Giane; MELO, Felipe Athayde Lins de. O encarceramento em massa em São Paulo. Tempo soc., São Paulo, v. 25, n. 1, p. 83-106, jun. 2013. Disponível em: http:// www.scielo.br/scielo.php?script=sci_arttext\&pid=S0103-20702013000100005\&lng=en\&nrm=iso.Acesso em: 07 jul. 2020

SOARES, Renata Araújo. O Estado de coisas inconstitucional e a calamidade do sistema penitenciário: diretrizes constitucionais para uma política transversal de segurança pública. 152 pp. Dissertação (Mestrado). Programa de Pós-graduação em Direito: Universidade Federal do Rio Grande do Norte. 2018. Disponível em: https://repositorio.ufrn.br/jspui/bitstream/123456789/26696/1/Estadocoisasinconstitucional_Soares_2018.pdf Acesso em: 07 jul. 2020.

STEINMETZ, Wilson; DE MARCO, Cristhian Magnus. A integridade física e moral dos presos: a intervenção do poder judiciário na política carcerária e a decisão do Supremo Tribunal Federal no recurso extraordinário n. 592.581. EJJL-Espaço Jurídico: Journal of Law, Chapecó, v. 16, n. 2, p. 655-666, ago. 2015.

VENTURI, Elton. Suspensão de liminares e sentenças contrárias ao Poder Público. 2.ed. São Paulo: Ed. RT, 2010. 
WALMSLEY, Roy. World Prison Population List. [s.l.]: Institute for Criminal Policy Research, 2015. Disponível em: http://www.prisonstudies.org/sites/default/files/resources/downloads/world_ prison_population_list_11th_edition_0.pdf. Acesso em: 27 mar. 2018.

YEPES, Rodrigo Uprimny. GUZMÁN, Diana Esther. Las Cárceles en Colombia: entre una Jurisprudencia Avanzada y un Estado de Cosas Inconstitucionales. In: SEGURA, Juan David Posada (coord.). III Simposio Internacional Penitenciario y de Derechos Humanos. Medellín: Universidad de San Buena Ventura, 2010, p. 145-164. Disponível em: https://www.oas.org/es/cidh/ppl/docs/ pdf/memoriasiiisimposiointernacional.pdf. Acesso em: 27 mar. 2018. 